\title{
Controlling orientation, conformation, and biorecognition of proteins on silane monolayers, conjugate polymers, and thermo-responsive polymer brushes: investigations using TOF-SIMS and principal component analysis
}

\author{
Katarzyna Gajos $^{1}$ (D) $\cdot$ Kamil Awsiuk $^{1}$ (D) $\cdot$ Andrzej Budkowski ${ }^{1}$ (D)
}

Received: 8 May 2020 / Revised: 1 July 2020 / Accepted: 16 July 2020 / Published online: 16 August 2020

(C) The Author(s) 2020

\begin{abstract}
Control over orientation and conformation of surface-immobilized proteins, determining their biological activity, plays a critical role in biointerface engineering. Specific protein state can be achieved with adjusted surface preparation and immobilization conditions through different types of protein-surface and protein-protein interactions, as outlined in this work. Time-of-flight secondary ion mass spectroscopy, combining surface sensitivity with excellent chemical specificity enhanced by multivariate data analysis, is the most suited surface analysis method to provide information about protein state. This work highlights recent applications of the multivariate principal component analysis of TOF-SIMS spectra to trace orientation and conformation changes of various proteins (antibody, bovine serum albumin, and streptavidin) immobilized by adsorption, specific binding, and covalent attachment on different surfaces, including self-assembled monolayers on silicon, solution-deposited polythiophenes, and thermo-responsive polymer brushes. Multivariate TOF-SIMS results correlate well with AFM data and binding assays for antibody-antigen and streptavidin-biotin recognition. Additionally, several novel extensions of the multivariate TOF-SIMS method are discussed.
\end{abstract}

Keywords TOF-SIMS $\cdot$ Proteins $\cdot$ Bioassays $\cdot$ Silane monolayers $\cdot$ Polythiophenes $\cdot$ Thermo-responsive polymer brushes

\section{Introduction}

Protein immobilization on a solid surface is essential for the development of biotechnological applications covering a wide range of areas, such as medical diagnostic, pollution screening, regenerative medicine, or drug delivery. Control over the proper state of immobilized proteins, involving their orientation and conformation that determine their biological activity, is essential to ensure an effective and reliable performance of analytical devices and systems, such as biosensors or protein and DNA microarrays. Moreover, some applications require induction by the surface of the desired biological response to

Katarzyna Gajos

katarzyna.gajos@uj.edu.pl

Andrzej Budkowski

andrzej.budkowski@uj.edu.pl

1 M. Smoluchowski Institute of Physics, Jagiellonian University, Łojasiewicza 11, 30-348 Kraków, Poland environmental stimuli. For instance, temperature-induced change in surface properties enables the harvesting of intact contagious cell sheets for tissue engineering [1]. To achieve these goals, recent studies have concentrated on the careful design of biointerfaces with tuned or switchable properties. The functionalization of the materials' surface by molecular or polymer layers is a versatile strategy, tailoring interface properties while preserving bulk characteristics [2]. Organic molecules forming self-assembled monolayers (SAMs) provide an effective and convenient method to introduce functional chemical groups on various surfaces, e.g., gold, siliconbased substrates, graphene, glass, or PDMS [3, 4]. SAMs can be applied to promote protein physical adsorption, e.g., thiols or silanes with the amine group, or to enable covalent protein binding, e.g., by the creation of aldehyde or NHS ester surface species. Due to the simple modification procedure and the ability to modify the materials used as sensors' transducers, SAMs are widely applied in functionalization protocols for protein immobilization on biosensors or bioassay surfaces [3-9]. Furthermore, polymers with the desirable type of 
interactions with biomolecules involving biocompatible [10], charged [11], anti-fouling [12], and stimuli-responsive [13] polymers can be applied to modify the surface properties of a variety of materials. This can be achieved by coating polymer layers on or by grafting polymer chains to or from the material surface. Thin polymer films, easily prepared by solution coating, not only enable a surface modification inducing the desired iterations with proteins but also can form functional elements of various devices, e.g., within organic electronics. In turn, polymer brushes can be formed by polymer chains tethered to surfaces using different methods. Effective functionalization of various materials is achieved with grafting from the surface, involving surface-initiated polymerization [14-16]. Among the variety of polymer brushes, those formed by stimuli-responsive polymers, changing significantly and reversibly their physico-chemical properties in response to slightly varied environmental conditions, attract special attention [13, 17]. Biotechnological applications of such brush coatings involve bioseparation, drug delivery, and tissue engineering, based on polymer interactions with biomolecules changed in a response to external stimuli [13, 17-19]. These interaction changes are relevant for the affinity to proteins or cells, as well as their behavior.

The state of proteins immobilized on a molecular and polymer surface by physical adsorption or covalent binding depends on protein-surface and protein-protein interactions [20]. These interactions are determined by the properties of both the surface and the protein as well as by external conditions such as temperature, $\mathrm{pH}$, and ion buffer strength. The protein state corresponds to its free energy minimum resulting, besides specific bindings, from electrostatic and van der Waals interactions, hydrogen bonds, and hydrophobic effects [20]. Proteins consist of one or more long chains of amino acids folded into a secondary structure and then organized into a tertiary and quaternary native protein structure, crucial for the protein biological function. For this reason, conformation changes of proteins upon adsorption on a solid surface, which can even lead to protein denaturation and a loss of biological activity, is an important issue in protein immobilization [20, 21]. In turn, the orientation of the protein immobilized on the surface determines the protein subunits interacting with the surface and those exposed to the solution. Orientation of immobilized proteins is especially important for functional proteins, such as enzymes, receptors, and antibodies with binding or reaction sites located on a certain part of the molecule. Therefore, for proteins acting as detecting molecules or components of bioaffinity techniques the orientation they adopt on the surface determines the access to their binding sites, and hence specifies assay efficiency $[22,23]$. A direct examination of the conformation and orientation changes of surface-immobilized proteins is a challenging issue. At the same time, many biotechnological applications are based on simple non-specific adsorption methods, which result in an unspecified or random orientation of proteins. Therefore, research efforts are focused on the development of both the methods of protein immobilization limiting conformation changes and providing the desired orientation, as well as the methods of protein state examination themselves. The conformation and orientation changes of a surface-immobilized protein are commonly deduced indirectly, based on biorecognition examination or the determination of the thickness and topography of the protein layers. As reviewed by Trilling et al. [22] and Welch et al. [24], the orientation of IgG antibodies, acting as detection elements of immunosensors and immunoassays, can be inferred from the antibodies surface density, when examined with techniques such as X-ray photoelectron spectroscopy, spectroscopic ellipsometry, surface plasmon resonance, quartz crystal microbalance, dual-polarization interferometry, or neutron reflectometry, and compared with their antigen-binding efficiency. Additionally, atomic force microscopy (AFM) of single proteins' height or protein layer topography [25-27] and Fourier-transform infrared spectroscopy (FTIR) [28] enable an examination of proteins' orientation and proteins' secondary structure, respectively. Furthermore, time-of-flight secondary ion mass spectrometry (TOF-SIMS) is an especially attractive method for protein state analysis: due to its excellent chemical specificity, it can directly probe the amino acid concentration of surface-immobilized proteins with a sensitivity peaked at their outermost region [29]. As a result, TOF-SIMS, supported by multivariate principal component data analysis, enables a comparison of the orientation and conformation of proteins immobilized not only on simple model substrates but also on functional molecular and polymer surfaces [24, 30-35]. Such a chemical glimpse at protein conformation and orientation can be provided, although the ultra-high vacuum conditions required by TOF-SIMS induce additional protein denaturation [36] that causes a potential drawback [24]. For the above reasons, the multivariate TOF-SIMS method provides information about protein state in a more direct manner than most other surface analysis methods [22, 24, 37].

A protein state examination with multivariate TOF-SIMS analysis is presented in the next section of this review. Then, we examine the factors determining protein orientation. Finally, the case studies of proteins immobilized on selfassembled monolayers, solution-deposited polythiophenes, and thermo-responsive polymer brushes are outlined.

\section{TOF-SIMS examination of the state of surface-immobilized proteins}

TOF-SIMS is a surface-sensitive spectroscopic technique, identifying secondary ions emitted from the surface upon bombardment by energetic primary ions (e.g., $\mathrm{Bi}^{+}, \mathrm{Cs}^{+}, \mathrm{Ga}^{+}$, $\mathrm{C}_{60}{ }^{+}$). Secondary ions, which are fragments of molecules 
forming the sample surface, are identified from the mass to charge ratio $(\mathrm{m} / \mathrm{z})$ measured by a time-of-flight mass analyzer and characterized by a mass resolution $m / \Delta m$ reaching 10,000 .

In the case of proteins immobilized on a substrate, a high mass resolution enables the identification of secondary ions as fragments of particular amino acids [38]. However, a careful choice of TOF-SIMS signals applied to further analysis is required due to the ambiguous assignment of the same ion fragments to amino acid residues [38-41] and a possible overlapping with signals derived from other materials, e.g., the substrate.

For an examination of the state of surface-immobilized proteins, the highly surface sensitive "static SIMS" regime is applied. In this operating regime, the dose density of primary ions is kept below $10^{12}$ ions $/ \mathrm{cm}^{2}$ to ensure that secondary ions originate only from intact sample areas [42]. TOF-SIMS surface sensitivity is characterized by the mean emission (attenuation) depth of secondary ions $\lambda \sim 0.6 \mathrm{~nm}$ [34] (this value for $\mathrm{Bi}_{3}{ }^{+}(30 \mathrm{keV})$ primary ions), indicating a much greater sensitivity for the outermost region of the protein layer (Fig. 1a). At the same time, the "escape" depth, determined as the thickness where a particular ion intensity is 3 standard deviations from the background [43], is about $3 \mathrm{~nm}$ for ions derived from organic films [34, 43]. This value corresponds to the protein surface density of $\sim 3.8 \mathrm{mg} / \mathrm{m}^{2}$ and reveals the TOF-SIMS ability to probe the complete protein monolayers.

The major disadvantage of the TOF-SIMS technique with respect to protein state analysis is the fact that it operates under ultra-high vacuum conditions. The examined protein layers are, therefore, dehydrated causing some rearrangement of the protein structure. However, a comparison of proteins orientation or the denaturation degree on different samples is still possible, since the composition of amino acids exposed to the interface during the TOF-SIMS measurement depends on the protein state before dehydration. To minimize alternations in protein conformation in UHV protection methods applying trehalose coating has been investigated [32, 44, 45]. However, they introduce trehalose-derived signals to TOFSIMS spectra and may mask protein-derived signals [32, 45]. The recent developments of the TOF-SIMS method include attempts at an "in situ" examination of protein layers in water, here possible thanks to a special microfluidic device [46-48].

Additionally, TOF-SIMS is not a quantitative method with the ion intensity being influenced by a number of factors. Therefore, the state of surface-immobilized proteins can be examined only by comparison with reference samples. Additionally, differences can be identified between the proteins state on different surfaces.

The most popular set used to analyze proteins immobilized into different surfaces consists of a liquid metal ion gun (LMIG) and a time-of-flight analyzer. The LMIG generates primary ions (single atoms or small clusters, mostly $\mathrm{Bi}$ or $\mathrm{Ga}$ ) which can be highly focused to attain a spot size of $\sim 100 \mathrm{~nm}$ at the sample surface. Unfortunately, metal clusters' impact on the underlying chemical structure and analysis can be performed only to the ion dose limit before the surface becomes extensively damaged. To overcome this limitation the relatively recent development of gas cluster sources (mostly consisting of thousands of Ar atoms) has been applied in SIMS. An argon gas cluster beam enables for low damage

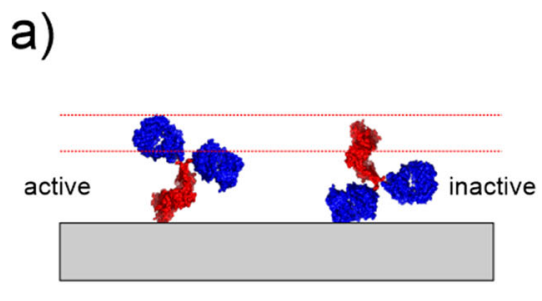

b)

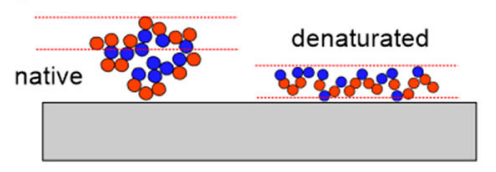

c)
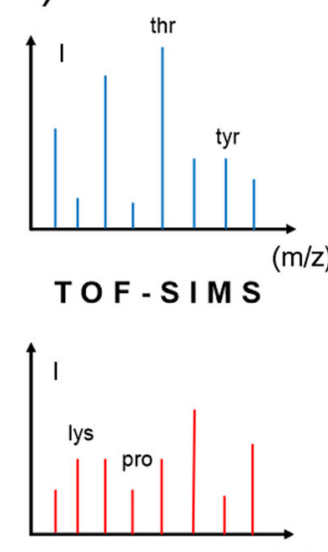

$(\mathrm{m} / \mathrm{z})$

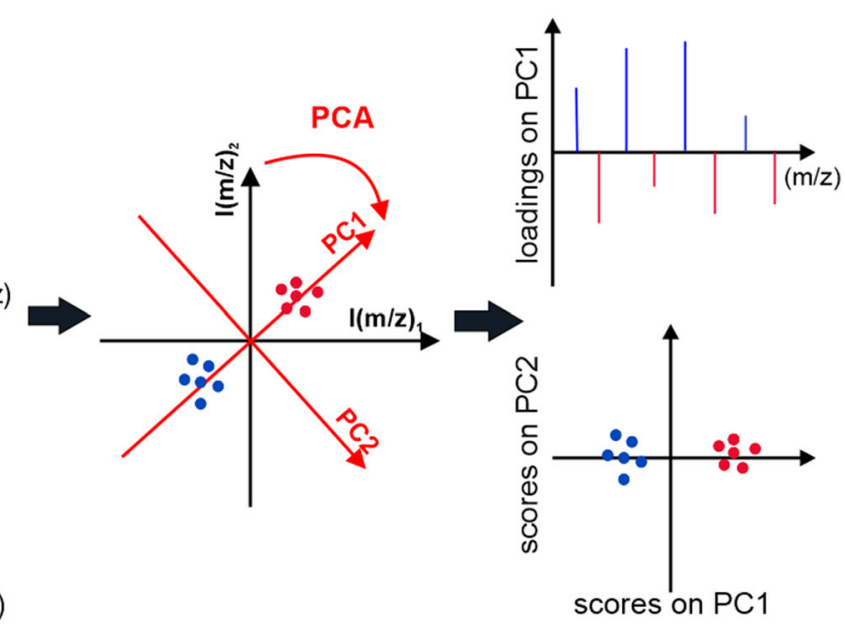

provided by many high-resolution TOF-SIMS spectra, is performed by the multivariate PCA method (c). The obtained principal components (PCs) capture the main sources of variability in the data set, incl. Differences in the protein state interpreted from the plots of loadings from particular mass signals. In turn, the plots of scores from particular TOFSIMS spectra separate samples according to the features maximized by PCs
Fig. 1 Analysis of protein orientation (a) or denaturation (conformation) (b), based on static TOF-SIMS sensitivity to the outermost region of the immobilized proteins (marked by red horizontal lines), and differences in the amino acid composition between the different protein domains (a) or between the buried and surface regions of a native protein (b), respectively. To maximize the differences in the measured amino acid composition, a simultaneous inspection of the intensities of many mass signals, 
surface analysis and the detection of intact peptides and proteins [49-51]. Another very important element which impacts on spectra quality is the mass analyzer. Typically this is a time-of-flight analyzer, where mass-to-charge ratios are determined by measuring the time that ions take to move through a drift (field-free) region (flight time is proportional to $(\mathrm{m} / \mathrm{z})^{0.5}$ ). Another very promising mass analyzer which employs trapping within an electrostatic field is orbitrap. Orbiting ions (trapped in the analyzer) perform harmonic oscillations along the electrode with a frequency proportional to $(\mathrm{m} / \mathrm{z})^{-0.5}$ which are observed using an image current and which are finally transformed into mass spectra using fast Fourier-transform [52]. An orbitrap mass analyzer is characterized by a much higher mass resolution $m / \Delta m>150,000$ than is a ToF analyzer. Recently, the potential of an orbitrap mass analyzer combined with a ToF, LMIG gas cluster gun in SIMS has been presented [53]. Such a combination of these four elements has provided a subcellular lateral resolution with a high massresolving power $>240,000$.

To process a large TOF-SIMS data set, recorded from complex multi-component surfaces, advanced multivariate data analysis [54] techniques are especially useful. Such techniques support the detection of differences between spectra and the identification of their major sources. Among different data analysis methods, multivariate principal component analysis is nowadays the most commonly applied for the examination of layers of surface-immobilized protein $[30,38,55]$ or biomaterials surfaces $[56,57]$. Each spectrum from the TOFSIMS data set can be visualized as a point in multidimensional space with the coordinate system (axes) spanned by intensities of particular secondary ions (Fig. 1c). PCA determines the sequential directions of the greatest uncorrelated variations within the data set (new axes of a new coordinate system) called principal components that capture the main sources of variability within the data set. PCA enables the reduction of the data set dimensionality while maintaining most of the original information. PCA results are provided as the plots of scores from particular TOF-SIMS spectra (points) that separate samples according to the features maximized by PCs, and the plot of loadings from particular mass signals that enable interpretations of PCs. PCA could also be applied to an analysis of TOF-SIMS 2D images [33, 58-60] and even 3D TOF-SIMS sputtering data [50]. Other multivariate methods already applied for TOF-SIMS data analysis are non-negative matrix factorization (NMF) [61, 62], the k-means cluster method [63], discriminant analysis [64, 65], and artificial neuronal networks $[55,66]$ involving self-organizing maps [67-71].

\section{Determination of protein orientation with TOF-SIMS}

Specific orientation of protein immobilized on the surface makes some protein domains direct themselves towards the substrate while others are exposed away from the substrate. The idea of TOF-SIMS analysis of protein orientation is based on the differences in the amino acid composition between different protein domains and on the surface sensitivity of TOF-SIMS technique (Fig. 1a). TOF-SIMS examines the molecular composition of the outermost region of the protein layer which is different for proteins adopting different orientations. Such an approach requires knowledge of the composition of amino acids in the domains of the examined protein from the protein data bank or an additional TOF-SIMS examination of reference samples with immobilized particular domains. Further, this approach gains when the relations between the intensities of particular amino acid derived ions rather than characteristic signals are considered. Therefore, multivariate data analysis is required. Still, some works have analyzed the ratio of particular ions derived from the amino acid abundant in individual domains [33, 72]. In PCA, the loadings on PCs from the mass signals of different amino acids are compared with the amino acid composition of distinct protein domains. This is to identify the principal component maximizing orientational differences and to separate the samples with a different orientation, based on the corresponding scores plot. To ensure a proper data interpretation, the results of protein orientation are usually juxtaposed with their examined biological activity.

The largest part of research efforts concentrates on an examination of the orientation of surface-immobilized antibodies due to their application in immunosensors and immunossays. Immunoglobuline $\mathrm{G}$ ( $\mathrm{IgG}$ ), most commonly employed as a capture molecule in immunosensors, consists of two heavy and two light chains forming constant and variable regions of the characteristic three-lobe $\mathrm{Y}$-shape structure with one Fc domain and two Fab domains. The Fc domain consists only of constant regions, while antigen-binding sites are located on the Fab domains forming molecule "arms". Therefore, the access to binding sites and antigen binging efficiency depends on antibody orientation involving flat-on (all domains attached to a surface), side-on ( $\mathrm{Fc}$ and one Fab domain attached to a surface), head-on (both Fab domains attached to surface and $\mathrm{Fc}$ facing up), and tail-on ( $\mathrm{Fc}$ domain attached to a surface and both Fab facing up) orientations [22]. TOF-SIMS with PCA was applied for the examination of the dominant orientation adopted by antibodies on a SAM modified gold [33, 37, 73] and silicon surface [34, 74], polymer layers $[28,33,35,55]$, and polymer brushes [75] as well as to determine the orientation of bioaffinity-bound antibodies [74, 76]. The studies performed so far have provided a comparison of a dominant antibody orientation on different surfaces and a definition of the factors determining protein orientation, the being latter discussed in detail in "Factors affecting protein orientation: examination illustrated with the antibody on self-assembled monolayers" of this review. TOF-SIMS analysis of antibody orientation can be hampered by the fact that 
the exact composition of amino acids in the domains of particular IgG antibody are often unknown. One solution to this problem is a simultaneous TOF-SIMS examination of reference samples with immobilized $\mathrm{Fc}$ and Fab domains [33, 34, 73]. Recently, Awsiuk et al. proposed to interpret the orientational order of an examined IgG antibody with an unknown amino acid composition of its domains, using the relation between the just obtained PCA loadings and the PCA loadings determined earlier [73] for an $\operatorname{IgG}$ with a known complete amino acid composition of the Fab and Fc domains $[35,75]$. This idea is based on the fact that the relative prevalence of amino acids contributing to each signal and originating from $\left.\mathrm{F}(\mathrm{ab})_{2}\right)_{2}$ versus $\mathrm{Fc}$ fragment is largely preserved for different antibodies regardless of their exact composition (as shown in [74] for the amino acid composition ratio in $\left.\mathrm{F}(\mathrm{ab})_{2}\right)_{2}$ and $\mathrm{Fc}$ subunits).

TOF-SIMS was also applied to determine the orientation of other functional proteins, mainly immobilized on molecular (i.e., SAM modified) surfaces. The surface orientation of proteins widely applied in bioaffinity techniques such as streptavidin [77] (on polymer layer) and protein G [72, 78] (on SAMs) was examined using TOF-SIMS. Relations between orientation and electrostatic interactions as well as biorecognition efficiency were reported. So far, the TOFSIMS technique has been successfully applied to analyze the surface orientation of proteins such as bovine serum albumin (BSA) [75], fibronectin [79], lysozyme [80], osteocalcin [81], cytochrome b5 [82], and $\beta$-lactoglobuline [83].

\section{TOF-SIMS examination of protein conformation changes}

TOF-SIMS analysis of protein conformation changes, involving their denaturation, is based, in a way similar to protein orientation analysis, on static TOF-SIMS sensitivity to the outermost region of immobilized proteins (Fig. 1b). In a native protein, hydrophilic amino acids are exposed on the protein surface, while hydrophobic ones are buried inside protein core. Therefore, protein denaturation causing structure disordering changes the amino acid composition of the outermost region of the protein layers, which is probed by TOFSIMS. By that means protein denaturation can be detected by multivariate analysis $[32,84,85]$ or characteristic ions ratio analysis [86] as an increase of the relative intensity of ions derived from hydrophobic amino acids such as alanine, isoleucine, leucine, methionine, phenylalanine, valine, tyrosine, tryptophan, or cysteine. Alternative approaches compare the intensity of the ion fragments of disulfide bonds from the cysteine stabilizing protein structure, as proposed by Killian et al. [87], or identify the characteristic signals serving as denaturation markers [36]. The developed TOF-SIMS analysis of the protein state enables an examination of the different factors causing protein denaturation, such as temperature [88], time in a dried state [36], application of protecting substances [32], or surface properties [84, 85]. Apart from protein denaturation examination, TOF-SIMS is tested to study other conformation changes such as the different exposure of protein binding sites [89].

\section{Factors affecting protein orientation: examination illustrated with antibody on self-assembled monolayers}

Protein immobilization can be accomplished by random or site-directed immobilization methods [22, 24, 90]. Random immobilization is simply realized by physical adsorption or the covalent binding through amino groups [22]. In turn, the oriented immobilization methods involve covalent attachment of engineered antibody fragments and bioaffinity techniques based on the application of intermediate biomolecules such as protein $\mathrm{G}$, antigen, or biotin-streptavidin system [22, 24, 90, 91]. Here, we discuss the random antibody immobilization which, however, often results in a specified dominant orientation induced by the appropriate protein-protein and proteinsurface interactions. Even covalently immobilized proteins undergo firstly physisorption during which one of the orientations can be favored [92].

The issue of the orientation of surface-immobilized proteins is especially important for antibodies in the multiprotein overlayers on a biosensors' transducer surface since it determines immunological recognition and biosensors performance. Recently, silicon-based surfaces are used as the material for the fabrication of novel biosensor transducers [93-95] or even for the cost-efficient mass production (using mainstream silicon technology) of complete lab-on-the-chip devices integrating arrays of multiple miniaturized biosensors [96]. Silicon surfaces are activated with silane selfassembled monolayers prior to their biofunctionalization [97]. Therefore, surface analysis methods including TOFSIMS have been applied to examine the antibodies, antigens, and blocking proteins adsorbed and covalently attached to silicon surfaces functionalized with organo-silanes for silicon-based biosensors [34, 74, 98-100]. In the following section, we discuss the TOF-SIMS examination of the factors affecting antibodies orientation, with focus on the surfaces modified with self-assembled monolayers, in particular the organo-silanes on silicon surfaces.

\section{Surface density-dependent antibodies orientation}

The surface density of immobilized proteins is one of the most important factors determining protein orientation [20, 22, 24, 101]. The increase of protein surface mass loading decreases the surface area accessible to single molecules, inducing their more vertical orientation. Here, the surface density-dependent 
orientation changes are discussed in relation to IgG antibody molecules. The commonly used simple relation between antibody surface density and their orientation, which assumes proteins highly ordered close packing, was predicted by Norde et al. [102]. This relation yields the values of mass loadings corresponding to a complete monolayer of $\mathrm{IgG}$ molecules adopting flat-on $\left(\sim 2 \mathrm{mg} / \mathrm{m}^{2}\right)$ or vertical head-on $\mid$ tail-on orientation $\left(2.6-5.5 \mathrm{mg} / \mathrm{m}^{2}\right.$ depending on the angle between Fab fragments). Therefore, the antibody surface density determined with various techniques, and referred to an antigenbinding efficiency, is often applied to infer antibody orientation $[22,24]$. The disadvantages of this approach are the ambiguities of orientations available for the same ranges of antibody surface density (e.g., head-on, tail-on, and side-on) and the questioned highly efficient close-packed arrangement of proteins on the surface [103]. In particular, the packing efficiency (jamming limit, around 0.55 ) of proteins is markedly smaller than that of close-packed molecules, as described by random sequential adsorption [103]. Therefore, significantly smaller values of mass loadings corresponding to the monolayers of IgG antibodies adopting a particular orientation are expected: $\sim 1.1-1.4 \mathrm{mg} / \mathrm{m}^{2}$ for flat-on, $\sim 1.9 \mathrm{mg} / \mathrm{m}^{2}$ for sideon and $\sim 2.2-2.4 \mathrm{mg} / \mathrm{m}^{2}$ for vertical tail-on/head-on orientation $\left(1.4-3.0 \mathrm{mg} / \mathrm{m}^{2}\right.$ for the different angle between the Fab fragments) [25].

Recently, systematic studies of the surface densitydependent orientation of antibodies covalently bound to SAM modified silicon substrates, tracing the orientation changes with multivariate TOF-SIMS analysis has been presented by Gajos et al. [34]. The PCA model developed for the bare substrate, three representative $\operatorname{IgG}$ layers with different mass loadings and the reference layers of $\mathrm{Fc}$ and $\mathrm{F}\left(\mathrm{ab} \mathrm{b}_{2}\right)_{2}$ antibody domains, enables an identification of the principal component (here PC3) maximizing the orientational differences, based on the loadings plot (Fig. 2a), and the separation of the samples with different orientation, based on corresponding scores plot. Subsequently, the TOF-SIMS data recorded for a number of samples with different mass loadings of immobilized IgG molecules were projected onto the PCA model, as proposed by Wang et al. [73], to trace the changes in $\mathrm{IgG}$ orientation as a function of protein surface density (Fig. $2 b$ ). The analysis of the mean values of the scores on PC3, plotted against the surface density of particular IgG layers, and compared with the values from reference $\mathrm{Fc}$ and $\left.\mathrm{F}(\mathrm{ab})_{2}\right)_{2}$ samples, allows for a lucid identification of the mass loadings ranges characteristic for a particular orientation. The obtained ranges of surface density, $<1.2 \mathrm{mg} / \mathrm{m}^{2}$ for flat-on, $1.2-2.2 \mathrm{mg} /$ $\mathrm{m}^{2}$ for side-on and $>2.2 \mathrm{mg} / \mathrm{m}^{2}$ for vertical tail-on/head-on orientation, confirm the lower (random) packing efficiency of the antibodies in the examined layers, in accord with the random sequential adsorption model [103]. In addition, the determined relation (Fig. 2b) enables a direct and well-defined assignment of the dominant vertical $\mathrm{IgG}$ orientation adopted for high mass loading. Since the corresponding values of the scores on PC3 (describing the $\mathrm{IgG}$ orientation change from exposed $\left.\mathrm{F}(\mathrm{ab})_{2}\right)_{2}$ to exposed $\mathrm{Fc}$ ) are higher than those corresponding to the side-on orientation, a dominant head-on arrangement is assigned. In turn, the opposite relation, with scores on PC3 for a high protein surface density lower than those for a side-on orientation would have indicated a mixed tail-on/head-on or dominant tail-on orientation [34].

\section{Protein-surface interactions induce orientations of adsorbed and chemically attached antibodies}

As discussed in the previous section, the protein surface density is one of the most important factors determining molecules orientation through short-ranged repulsive proteinprotein interactions. Among more complex protein-surface interactions the most important are electrostatic forces. The impact of these interactions on surface protein orientation is caused by an asymmetry in the charge distribution within protein molecules and depends on the buffer $\mathrm{pH}$, buffer ion strength, and the surface charge. For the IgG molecule, the $\mathrm{Fc}$ and $\mathrm{F}\left(\mathrm{ab} \mathrm{b}^{\prime}\right)_{2}$ domains are characterized by the distinct values of the isoelectric point IEP [73, 104]. Therefore, opposite charges, negative within $\mathrm{Fc}$ and positive within $\mathrm{F}\left(\mathrm{ab} \mathrm{b}_{2}\right)_{2}$ fragments, can be induced even at a $\mathrm{pH}$ close to the IEP of the whole molecule. As a result, the whole IgG molecule has an electric dipole pointing from the $\mathrm{Fc}$ to the $\left.\mathrm{F}(\mathrm{ab})_{2}\right)_{2}$ fragment, which can be aligned in tail-on or head-on orientation depending on the surface charge [73, 104, 105] (Fig. 3e). The control of antibody orientation by electrostatic interactions was reported for charged self-assembled monolayers [26, 73, 105] and polymers $[35,102,106]$. However, the real orientation adopted by proteins depends not only on the surface design but also on the strength of the electrostatic interactions [34], influenced by environmental conditions such as buffer $\mathrm{pH}$ and ion strength, and competing with the effects of proteins surface density [74] and possible affinity binding [74].

Examination of $\operatorname{IgG}$ molecules orientation in multiprotein layers, corresponding to an indirect competitive immunoassay for the detection of ochratoxine A (OTA) and performed on silicon biosensors surface activated with a silane monolayer, has been reported recently [74] (Fig. 3). The performed PCA analysis involves the layers corresponding to the two final steps $(4,5)$ of the assay with the specific binding of the primary (OTA specific mouse monoclonal antibody, IgG) and secondary (goat anti-mouse antibody, anti-IgG) antibody, as well as to the two reference surfaces with $\operatorname{IgG}(\mathrm{r} 4)$ and anti$\operatorname{IgG}(\mathrm{r} 5)$ antibodies adsorbed physically with a low and high surface density, respectively. Multiprotein layers of the assay consist also of the conjugate of ochratoxin and ovalbumin (OTA-OVA), and bovine serum albumin (BSA) used to block free surface sites prior to immunoreactions. In the developed PCA model the PC1 discriminates between the layers with 


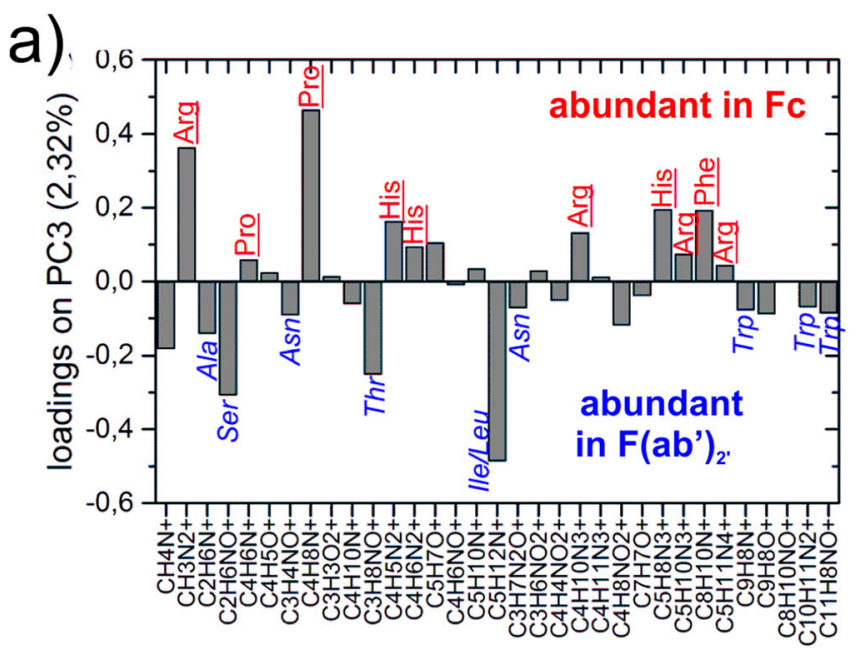

C)

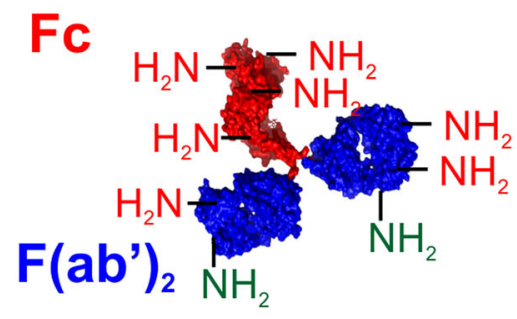

Lys

$\mathrm{pKa}=9.3-9.5$

$\mathrm{N}$-terminus $\mathrm{pKa}=7.6-8.0$

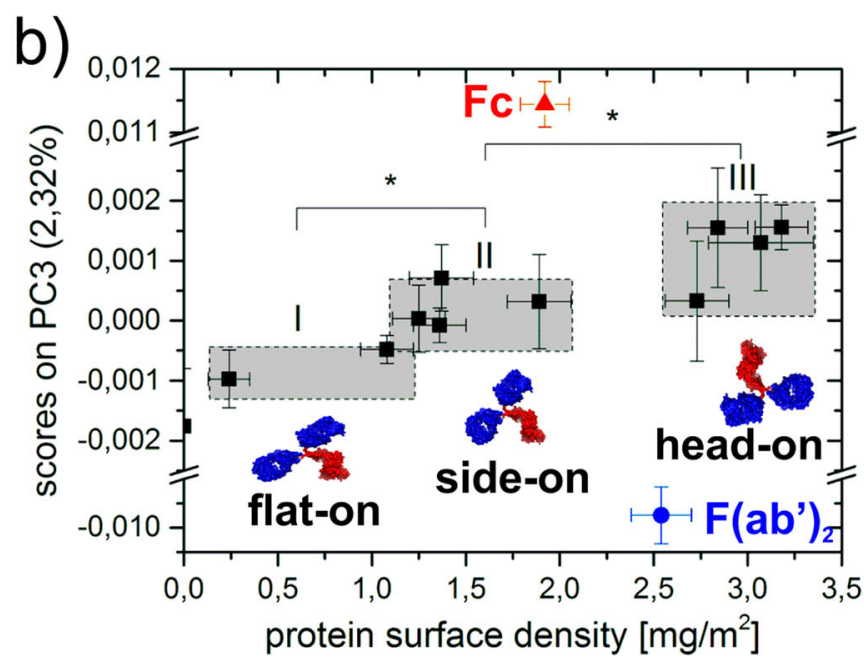

d)

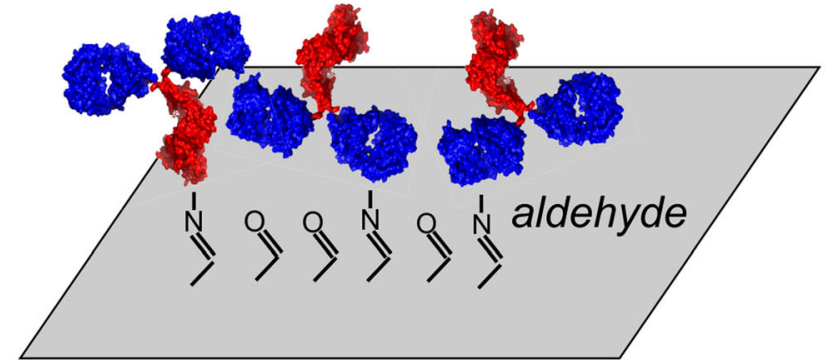

values (confirmed by AFM examination [34]), that accord with the random rather than close packing of proteins. (c) Protein covalent attachment to the aldehyde modified surface occurs by a reaction with the $\alpha$-amine of the N-terminus, located on $\mathrm{F}(\mathrm{ab})_{2}$, and the $\varepsilon$-amine of lysine randomly distributed between the $\mathrm{F}\left(\mathrm{ab}^{\prime}\right)_{2}$ and $\mathrm{Fc}$ domains. At a neutral $\mathrm{pH}$, amine groups of the $\mathrm{N}$-terminus are more reactive than the more protonated amine groups of lysine (with a higher acid dissociation constant $\mathrm{pKa}$ ). Together with random immobilization through lysine residues, they lead to a preferred head-on IgG orientation at high surface density values

with the specific Fab binding to the immobilized OTA-OVA molecule leads to the side-on orientation for the primary antibody $\operatorname{IgG}(\mathrm{r} 4)$, incorporated in the multiprotein monolayer (consisting also of OTA-OVA and BSA molecules). Finally, the high density of the anti-IgG secondary antibody specifically bound to primary antibodies embedded in the protein layer (5) leads to its head-on orientation.

It should be stressed, that electrostatic interactions can occur not only between protein and surface but also between proteins themselves [20]. As reported recently, the interaction between $\operatorname{IgG}$ molecules dipoles can lead to molecular alignment with a mixed tail-on/head-on orientation for high protein surface density [34].

Another factor influencing the orientation of covalently attached antibodies is the distribution on the protein molecule and reactivity of functional groups used for covalent immobilization. The most commonly applied approach for covalent protein binding involves the reaction of surface functional served. In turn, the combination of electrostatic interactions 
a)
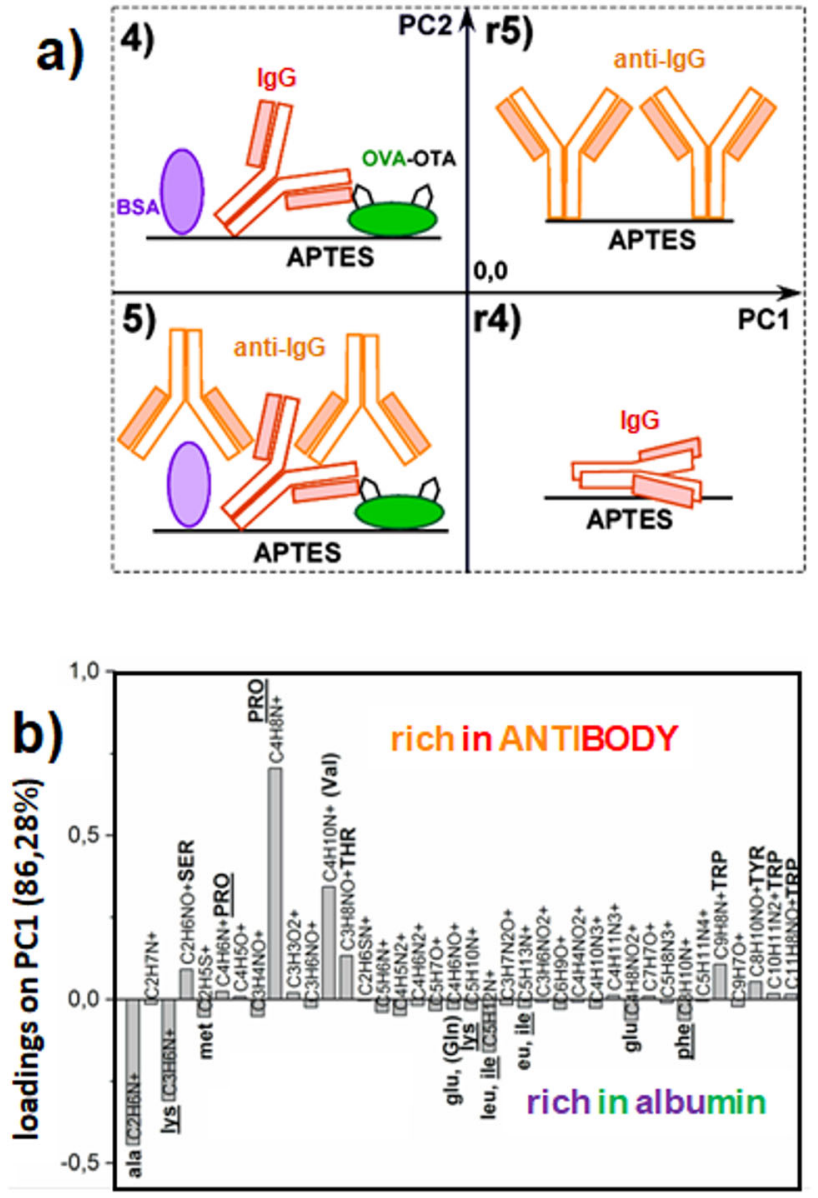
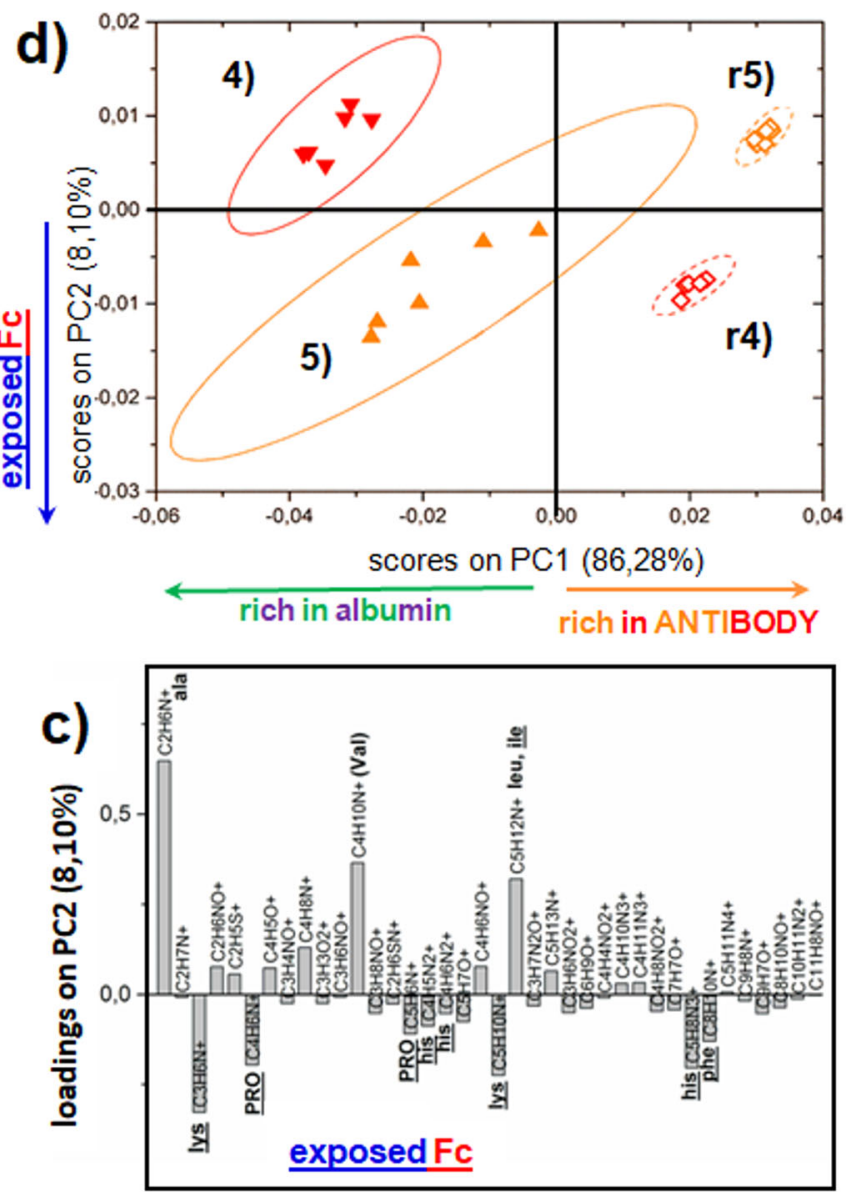

\section{e) $F\left(a b^{\prime}\right)_{2}$ IEP 8.5 \\ $\mathrm{Fc}$ \\ IEP 6.1

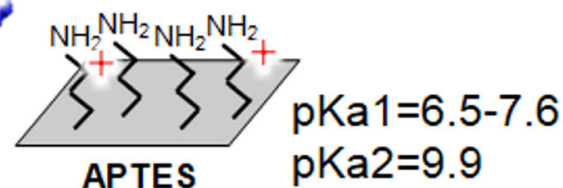

signals of amino acids with a higher abundance in Fc fragmentindicating an antibody orientation that exposes the Fc domain. (d) Scores plot with 4 groups of data points, centered in different quadrants of the coordinate system $\mathrm{PC} 1$ vs. PC2, corresponding to the samples introduced in (a). (e) At neutral $\mathrm{pH}, \mathrm{Fc}$ and $\mathrm{F}\left(\mathrm{ab}^{\prime}\right)_{2}$ domains (with different isoelectric points IEPs) are charged negatively and positively, respectively, and form an electric dipole, while the aminosilane modified surface can be charged positively. The dominant orientation (a) of physically adsorbed antibodies changes from flat-on (r4) to end-on (r5) as the surface coverage with the IgG increases due to the accumulation of electric dipoles. In turn, the orientation of immunoadsorbed antibodies changes from side-on (4) to head-on (5) as the molar binding ratio increases groups such as aldehyde, NHS ester, or epoxy groups with primary protein amines groups, i.e., $\mathrm{N}$-terminus $\alpha$-amine located on the $\mathrm{F}(\mathrm{ab})_{2}$ and $\varepsilon$-amine of lysine residues. In neutral $\mathrm{pH}$ conditions both of them are reactive, however, N-terminus $\alpha$-amine with a $\mathrm{pKa} \sim 7.6-8.0$ value lower the lysine $\varepsilon$-amine residues (pKa $\sim 9.3-9.5)$ exhibits a lower protonation and a higher reactivity. In IgG molecules, lysine residues are randomly distributed between the $\mathrm{Fc}$ and two Fab domains, while the $\alpha$-amine groups of $\mathrm{N}$-terminus are located on the $\mathrm{Fab}$ domains (Fig. 2c). Therefore, the head-on orientation can be promoted during $\operatorname{IgG}$ coupling through the protein amines [34] (Fig. 2d), which depends, however, on the solution $\mathrm{pH}$. 


\section{Proteins state on electroactive conducting polymers}

Electroactive conducting polymers, such as two types of polythiophenes, poly(3-alkylthiophenes), and poly( $3,3^{\prime \prime \prime}-$ didodecylquaterthiophene) PQT12, are electroactive as they exhibit a rapid and reversible redox switching between different oxidation states. Oxidation of these polymers can be achieved involving molecular dopant (A-), counter-balanced by a positively charged conjugated backbone [107]. Proteins including antibodies act readily as molecular dopants and can be even incorporated into conducting polymers [108] (Fig. 4a). Similarly, upon the contact of polythiophene surfaces with protein solution, positively charged conjugated backbones can impose an effective electrostatic field acting on the electric dipoles of proteins (Fig. 6) or their subunits (Fig. 7). The functionalization of conducting polymer surfaces with proteins, exemplified here by physical adsorption $[110,111]$, results in diverse applications, such as biosensors and bioelectronics [107, 108, 110-112] or tissue engineering and regenerative medicine [113-115]. This is due to the electronic properties of biocompatible [114] conducting polymers, which enable molecular recognition for signal transduction $[116,117]$ or the electrical control of interfacial properties [108, 118], as well as easy solution processing compatible with large-area surfaces and flexible substrates.

The architecture of poly(3-alkylthiophenes) determines their conducting properties [119]. Solubility-providing alkyl side chains are attached to the conjugated backbone of thiophene rings in a pattern specified by head-to-tail (HT) couplings. HT regioregularity induces a crystalline order [120] that dramatically improves conductivity [120]. Solutiondeposited regiorandom poly(3-alkylthiophenes) P3ATs are amorphous, but their regioregular counterparts RP3ATs are semi-crystalline with self-oriented crystallites [119] (Fig. $4 b)$. Strongly enhanced charge carrier mobility is provided by edge-on textured crystallites, with separated layers of conjugated backbones and insulating alkyl groups forming the lamellae parallel to the film substrate. Crystallites with a similar lamellar structure are formed by the solution-deposited films of PQT12 [121].

TOF-SIMS, enhanced with PCA, can resolve solutiondeposited films of polythiophenes with a different crystalline order (Fig. 4b-d). Conjugated backbones and alkyl side chains, accessed by TOF-SIMS, correspond to the amorphous morphology of P3ATs and to the edge-on textured crystallites of RP3ATs, respectively. Such a crystalline order (increasing along with the series $\mathrm{P} 3 \mathrm{BT}<\mathrm{RP} 3 \mathrm{HT}<\mathrm{RP} 3 \mathrm{BT}<\mathrm{PQT} 12[35$, 77]) can affect protein conformation (Fig. 5) and improve the electrostatic interactions that control protein orientation (Figs. 6 and 7). This is due to the exposure of hydrophobic alkyl side chains and a stronger effective electrostatic field, respectively.

\section{Conformation changes dependent on polymer crystallinity}

Conformational changes of proteins on modified substrates previously were reported to have been revealed by a multivariate TOF-SIMS analysis that separated amino acids into two groups, identified simply as hydrophobic and hydrophilic [30, $85,87,88,122]$. A more rigorous approach to examine protein conformational changes derived from TOF-SIMS data,
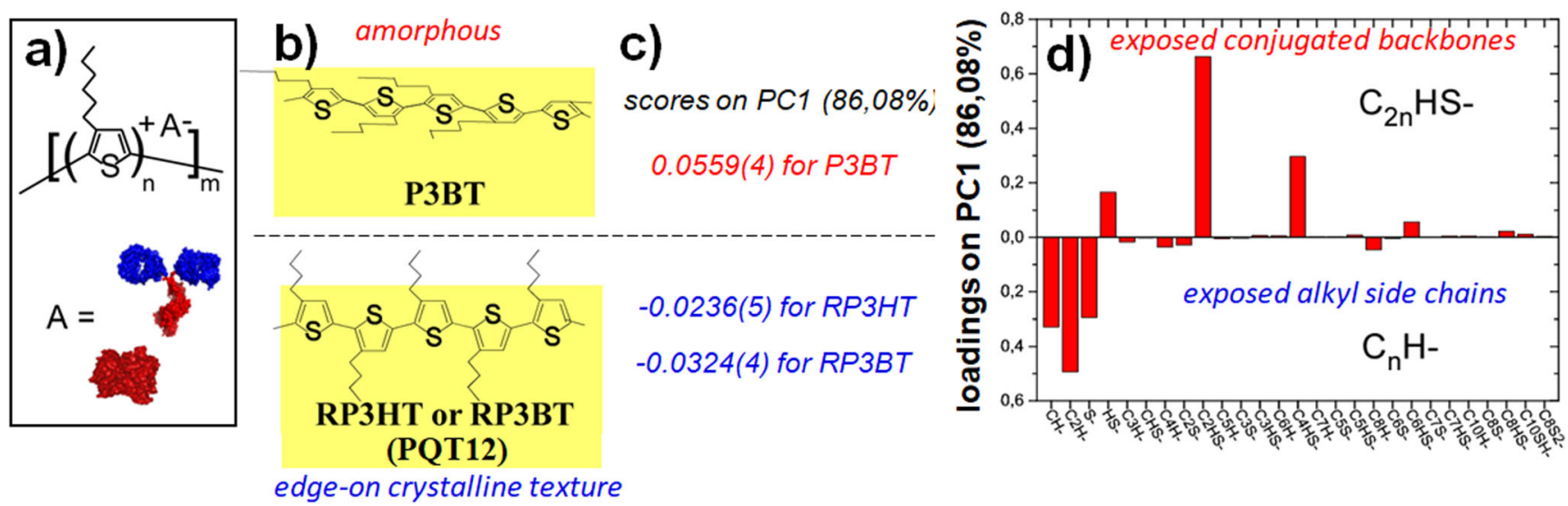

Fig. 4 (a) Electroactive poly(3-alkylthiophenes) (or poly(3,3"'didodecylquaterthiophene), PQT12, sketched in Fig. 7) are built of solubility-providing alkyl side chains and a conjugated backbone of thiophene rings. The latter can be positively charged due to oxidation, involving molecular dopant (anions $\mathrm{A}^{-}$). Proteins can act as molecular dopants, leading to electrostatic protein-polymer interactions (Figs. 6 and 7). (b) Alkyl side chains are attached to the backbone in a pattern specified by head-to-tail (HT) couplings. (c, d) Multivariate analysis [35] separates solution-deposited regiorandom (P3ATs) and regioregular (RP3ATs) poly(3-alkylthiophenes). Conjugated backbones and alkyl side chains, accessed by TOF-SIMS, correspond to the amorphous morphology of P3ATs and to the edge-on textured crystallites of RP3ATs, respectively. Such a crystalline order (increasing along with the series $\mathrm{P} 3 \mathrm{BT}<\mathrm{RP} 3 \mathrm{HT}$ $<$ RP3BT $<$ PQT12 $[35,77]$ ) can affect protein conformation (Fig. 5) and improve the electrostatic interactions that control protein orientation (Figs. 6 and 7) 
$\lg G$

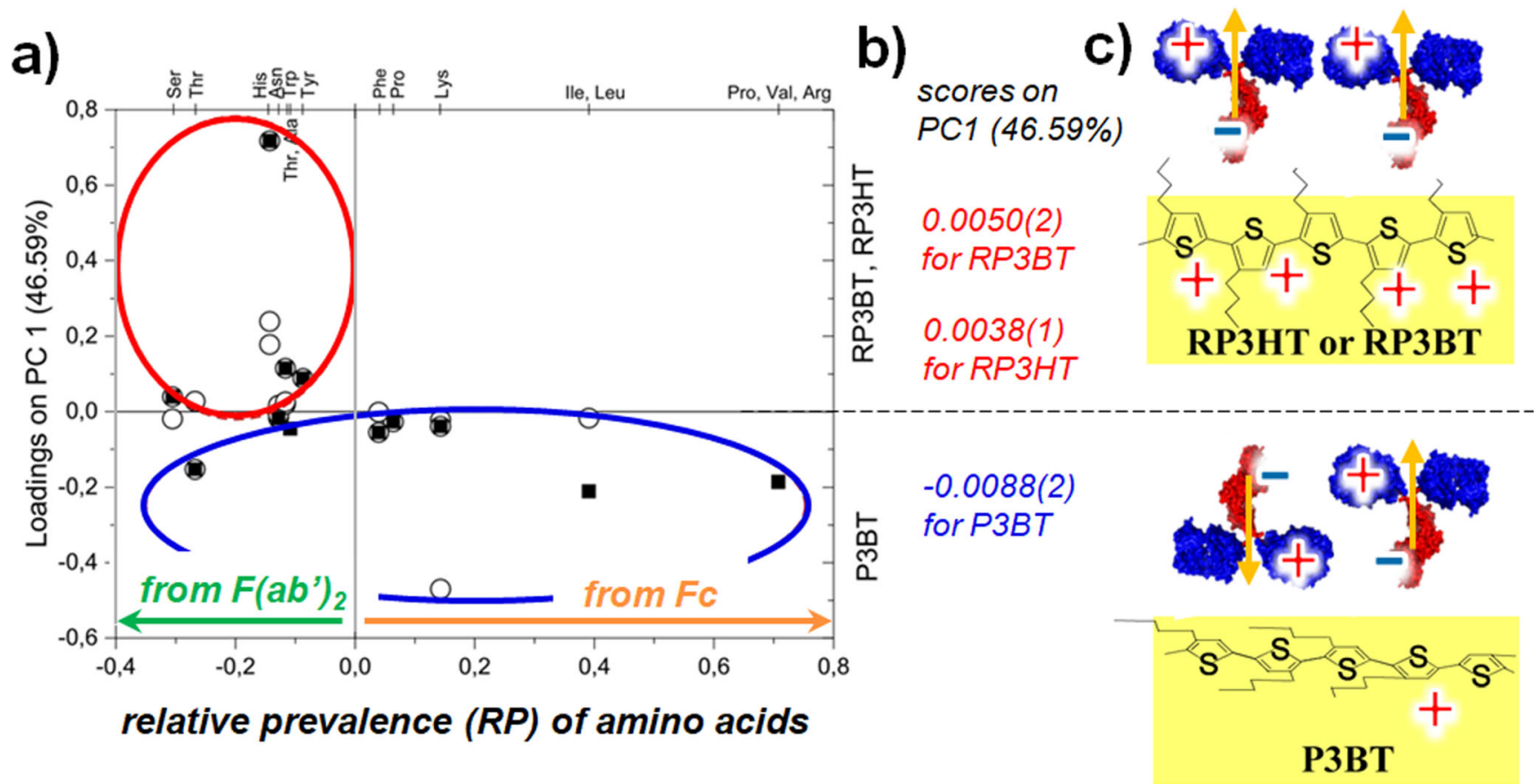

Fig. 6 Analysis of the IgG antibody orientation on solution-deposited amorphous P3BT and semi-crystalline RP3ATs [35], with an edge-on textured crystallinity better developed for RP3BT than RP3HT. (a) Loadings on the PC1 from the mass signals of the $\operatorname{IgG}$ plotted as a function of the relative prevalence, RP, of amino acids contributing to each signal and originating from the $\mathrm{F}(\mathrm{ab})_{2}$ versus the $\mathrm{Fc}$ fragment (for ion fragments (solid squares) and/or for amino acids (open circles) identical to those of the Ref. [73]). The RP parameter is defined [73] by the loadings plot of another analysis made for a model antibody and its fragments $\left.\mathrm{F}(\mathrm{ab})_{2}\right)_{2}$ (negative RP values) and $\mathrm{Fc}$ (positive RP values). (b) The corresponding values of the scores on the PC1 separate the samples of the IgG antibody adsorbed to P3BT and both RP3ATs. (c) The concluded exposure of the antibody fragments: $\left.\mathrm{F}(\mathrm{ab})_{2}\right)_{2}$ for RP3BT and RP3HT (end-on orientation), both $\mathrm{Fc}$ and $\left.\mathrm{F}(\mathrm{ab})_{2}\right)_{2}$ for P3BT (a mixed head-on/end-on orientation). Poly(3-alkylthiophene) crystallinity enhances the effective electrostatic field ordering the $\mathrm{IgG}$ electric dipoles. Such a field is less effective for P3BT, where intermolecular dipoledipole interactions promote an anti-ferroelectric pattern of protein dipoles a)

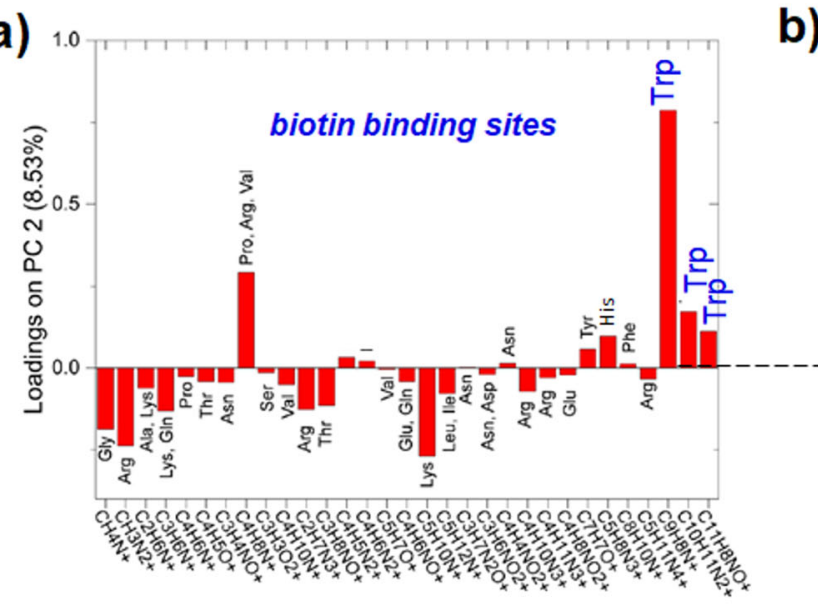

Fig. 7 Multivariate analysis [77] of the orientation of biotin-binding sites in streptavidin on solution-deposited amorphous P3BT and semicrystalline polythiophenes, with an edge-on textured crystallinity, developed better for poly (3,3"'-didodecylquaterthiophene) (PQT12) than RP3HT. (a) Loadings plot shows that the PC2 is loaded positively by mass signals of Trp abundant in biotin-binding sites. Any correlation between the PC2 and conformational changes is excluded (based on the analysis presented in Fig. 5). (b) The scores on the PC2 separate the samples of streptavidin adsorbed to P3BT, RP3HT and PQT12. (c)

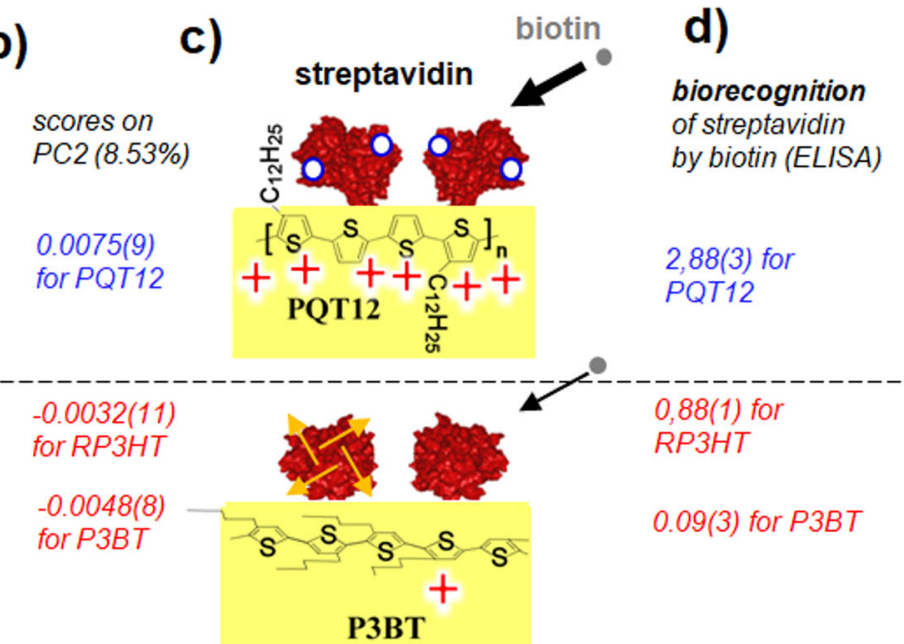

Polythiophene crystallinity enhances an effective electrostatic field interacting with the electric dipoles of 4 streptavidin subunits that orient or change slightly its quaternary structure in a way whereby the biotinbinding sites are more exposed. (d) Biorecognition of streptavidin by biotin, determined through an enzyme-linked immunosorbent assay. The relative amount of biotin bound to streptavidin adsorbed to PQT12 is 3 times higher than is corresponding to RP3HT, while the streptavidin on P3BT has lost its biological activity almost completely 


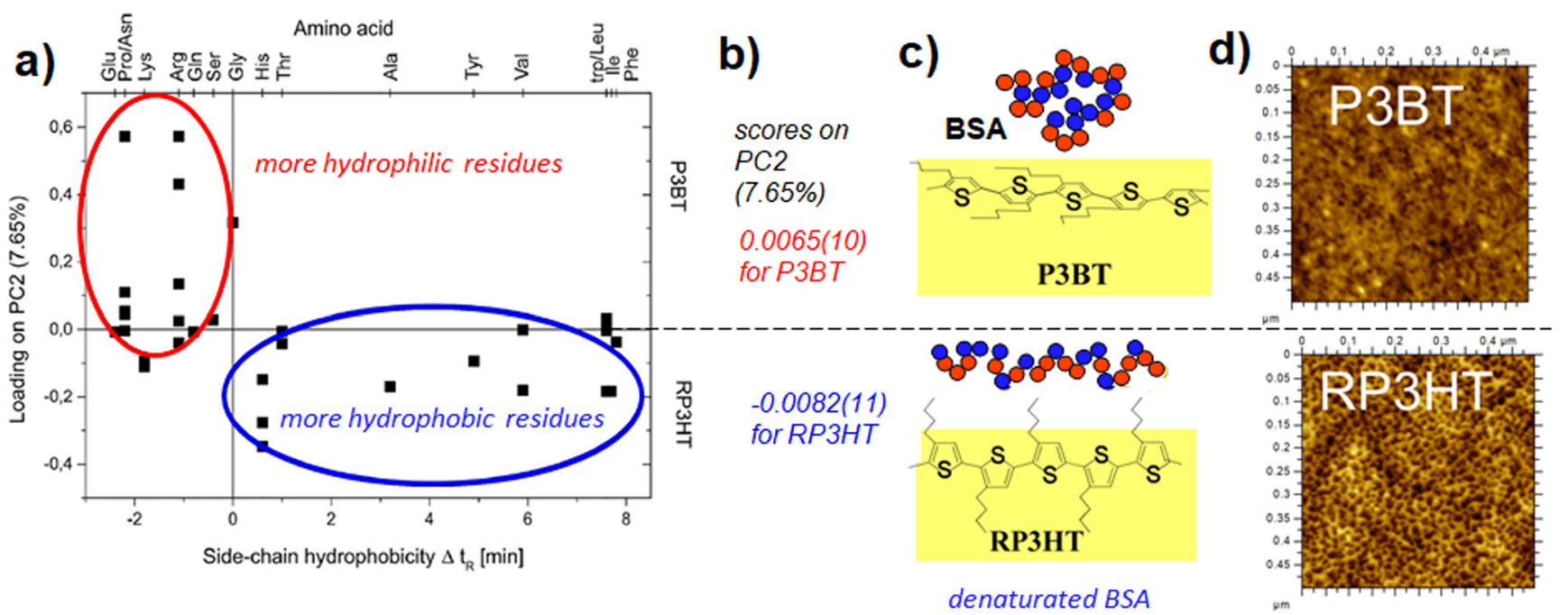

Fig. 5 Analysis of the conformational changes of bovine serum albumin (BSA) adsorbed to regiorandom P3BT and regioregular RP3HT (with similar wettability) [84]. (a) Loadings on the PC2 from the amino acid ion fragments of BSA plotted for each amino acid as a function of its sidechain hydrophobicity, defined [109] as the difference in RPC retention time $\Delta t_{R}$, relative to the Gly peptide, of a peptide analogue differing only by one amino acid residue. Amino acids more hydrophobic and more hydrophilic than Gly are marked by ellipses. (b) The corresponding values of the scores on the PC2 separate samples of BSA adsorbed on

introduced in [84] and presented in Fig. 5a, relates the loadings on the principal component (here $\mathrm{PC} 2$ ) from different amino acids with their side-chain hydrophobicity. A relative measure of the hydrophobicity of amino acid sidechains is provided by the results [109] of reversed-phase chromatography (RPC) and defined [109] as the difference in RPC retention time $\Delta t_{R}$, relative to the Gly peptide, of a peptide analogue differing only by one amino acid residue.

A new approach is applied (Fig. 5) to detect the conformational changes of bovine serum albumin (BSA) adsorbed to regiorandom $\mathrm{P} 3 \mathrm{BT}$ and regioregular RP3HT surfaces with a similar wettability (water contact angle $92.7(1.5)^{\circ}$ and $97.4(5)^{\circ}$, respectively). The principal component $\mathrm{PC} 2$ is loaded in the negative and positive direction by amino acids more hydrophobic and more hydrophilic than Gly, as marked by ellipses (Fig. 5a). The corresponding negative and positive, respective values of the scores on the PC2 separate the samples of BSA adsorbed on RP3HT from those immobilized on P3BT (Fig. 5b). Hydrophobic residues, not expected for a native protein, evidence a higher degree of BSA denaturation on crystalline RP3HT rather than amorphous P3BT films (Fig. $5 c)$. The conformation change of BSA can be induced by hydrophobic interactions [20], involving nonpolar BSA residues and nonpolar alkyl side chains accessible on the surface of edge-on textured polythiophene crystallites (Fig. 4). In addition, the enhanced exposure of hydrophobic BSA residues increases the protein-protein interactions, leading to BSA clusters observed by AFM as a patch-like morphology of protein coverage (Fig. 5d).
RP3HT from those immobilized on P3BT. (c) The higher degree of BSA denaturation on crystalline RP3HT rather than amorphous P3BT films is evidenced by hydrophobic residues, ones not expected for a native protein. Conformation change can be induced by hydrophobic interactions [20], involving nonpolar BSA residues and nonpolar alkyl side chains exposed by the edge-on textured polythiophene crystallites (Fig. 4). (d) Enhanced exposure of hydrophobic BSA residues increases proteinprotein interactions, leading to BSA clusters observed by AFM as a patch-like morphology of protein coverage

\section{Polymer crystallinity determining proteins' orientation and biorecognition}

The impact of the edge-on textured crystallinity of electroactive polythiophene on a protein's orientation and biorecognition is examined for two proteins, the IgG antibody (Fig. 6) and streptavidin (Fig. 7), adsorbed to two series of solution-deposited polymers with an increasing crystalline order, $\mathrm{P} 3 \mathrm{BT}<\mathrm{RP} 3 \mathrm{HT}<\mathrm{RP} 3 \mathrm{BT}$ [35] (Fig. 6) and P3BT $<$ RP3HT $<$ PQT12 [77] (Fig. 7). For both adsorbed proteins, multivariate PCA analysis of the protein mass signals separates the samples according to the increasing crystallinity of the polymer substrate (see the scores on the principal component in Figs. $6 \mathrm{~b}$ and $7 \mathrm{~b}$ ). This rather puzzling observation is simply explained by the correlation between the polymer crystallinity and the differences in the protein state that are maximized by the principal component. To interpret these differences further, the loadings plots are analyzed pointing to the varied orientational order of both proteins rather than their conformational changes $[35,77]$.

In the case of the adsorbed IgG antibody, the antibody orientation changes are examined with an approach introduced in [35] and presented in Fig. 6a. This relates the loadings on $\mathrm{PC} 1$ with the amino acids that contribute to the TOFSIMS signals and which do not correspond merely to individual amino acids, as commonly used, but even to their pairs or triplets. The loadings on the PC1 from the TOF-SIMS signals of IgG (Fig. 6a) are plotted as a function of the relative prevalence, RP, of amino acids, contributing to each signal and 
originating from the $F(a b)_{2}$ versus the $F c$ fragment. The RP parameter is defined [73] by the loadings plot of another analysis made for a model antibody and its fragments $\mathrm{F}\left(\mathrm{ab} \mathrm{b}_{2}\right.$ (negative RP values) and $\mathrm{Fc}$ (positive RP values). The negative loadings on the $\mathrm{PC} 1$ originate from the amino acids with both negative and positive RP values (blue ellipse), characteristic for a mixed head-on/end-on orientation, and these induce negative PC1 scores corresponding to the amorphous P3BT (Fig. $6 \mathrm{a}-\mathrm{c}$ ). In turn, the positive loadings on the $\mathrm{PC} 1$ originate from the amino acids with negative RP values (red ellipse), corresponding to end-on orientation, and induce the positive PC1 scores characteristic for semi-crystalline RP3ATs.

The orientational order of the adsorbed IgG antibody (expressed by the scores on the PC1, Fig. 6b), increases with the crystallinity of the electroactive poly(3alkylthiophene) substrates. This is because positively charged conjugated backbones form well-ordered and densely packed chains in the edge-on oriented crystallites, which enhance an effective electrostatic field ordering the IgG electric dipoles. Such a field is less effective for an amorphous $\mathrm{P} 3 \mathrm{BT}$, and therefore intermolecular dipoledipole interactions promote the anti-ferroelectric pattern of the protein dipoles (Fig. 6c).

In the case of adsorbed streptavidin, protein orientation changes are examined with the plot of loadings on the PC2 (Fig. 7a). PC2 is loaded positively by the mass signals of tryptophan abundant in biotin-binding sites. Also, an analysis similar to that of Fig. 5 excluded any correlation between the PC2 and conformational changes. Therefore, orientation change of biotin-binding sites in streptavidin is concluded. Also, the exposure of these sites is enhanced with the edge-on textured crystallinity of polythiophene, since positive loadings on the PC2 induce positive PC2 scores (Fig. 7a-c). As explained above, polythiophene crystallinity enhances an effective electrostatic field. This field interacts with the electric dipoles of 4 streptavidin subunits, and orients or changes slightly its quaternary structure in a way whereby the biotin-binding sites are more exposed. Changes in streptavidin orientation, determined from multivariate TOF-SIMS characterizations, are correlated well with the results of binding assays performed for streptavidin-biotin recognition (Fig. 7d). The relative amount of biotin bound to streptavidin adsorbed to PQT12 is 3 times higher than that corresponding to RP3HT, while the streptavidin on P3BT has lost its biological activity almost completely.

\section{Temperature-controlled proteins state on stimuli-responsive polymer brushes}

Polymer brushes are formed by chains attached with one (modified) end to an interface using adsorption [123] or grafting to a surface [16]. Alternatively, a chain is grafted from the surface by surface-initiated polymerization, enabling the effective functionalization of other materials. Although conformational brush changes can be driven by both entropy [124] or enthalpy [125], the latter finds more biomedical applications. In particular, the coil-to-globule transition exhibited in aqueous solutions by the brushes of polymers with lower critical solution temperature (LCST) can be used for temperature-controlled cell behavior (e.g., cell sheet engineering $[1,126])$ and protein adsorption $[127,128]$. In addition, some of these coatings exhibit a dual temperature and $\mathrm{pH}$ response. A TOF-SIMS and PCA examination of the antibody adsorbed on thermo-responsive plasma polymerized surface below and above its LCST pointed to different conformations or orientations, confirmed by different protein's biological activity [129].

Practically all the biomedical applications of thermoresponsive polymer brushes reported so far use LCST transition as a temperature response mechanism. Recently, a novel approach to gain temperature sensitivity has been demonstrated, involving a glassy-to-rubbery state transition: in particular, examined has been a grafted brush of poly(n-butyl methacrylate) (PBMA) attached to the glass, with a glass transition temperature $\left(T_{\mathrm{g}}\right.$ around $\left.13-25^{\circ} \mathrm{C}\right)$ within the range of physiological temperatures [75]. Its properties are depicted in Fig. 8: the temperature-driven transition from a glassy to a rubbery state induces dramatic changes in polymer elasticity and modifies the surface topography-from nanostructured to a smooth surface. The latter results in a noticeable variation in the surface RMS roughness, with changes larger (Fig. 8b) than those between amorphous and semi-crystalline polythiophenes $\left(\Delta_{\mathrm{RMS}} \sim 1-2 \mathrm{~nm}\right)$. Both the surface topography and polymer elasticity effects seem to be responsible for the temperature-controlled adsorption (Fig. 8d) and orientation of the proteins (Figs. 9 and 10) adsorbed on temperature-responsive PBMA grafted brushes at different temperatures. Such a conclusion is drawn, based on the disregarded main factors determining the behavior of an adsorbed protein, such as the electrostatic interactions of the brush with charged proteins' domains (yielding opposite predictions for BSA and the anti-IgG, cf. Figs. 9a and 10a). Equally, the variations across $T_{g}$ of the polar and apolar components of the PBMA surface energy, reflecting van der Waals-London interactions and hydrogen bonding, are too small ( $<9 \%$ of their absolute values) to induce the protein's response [75]. Finally, the above conclusion is in accord with the recent studies that have demonstrated the role of interactions between proteins and surface topographies [133, 134], or the impact of polymer elasticity (flexibility) [135] on the state of immobilized proteins.

\section{The temperature-controlled orientation of protein with preserved conformation}

A PCA analysis of TOF-SIMS signals originating from the amino acids of BSA, adsorbed on the temperature-responsive 

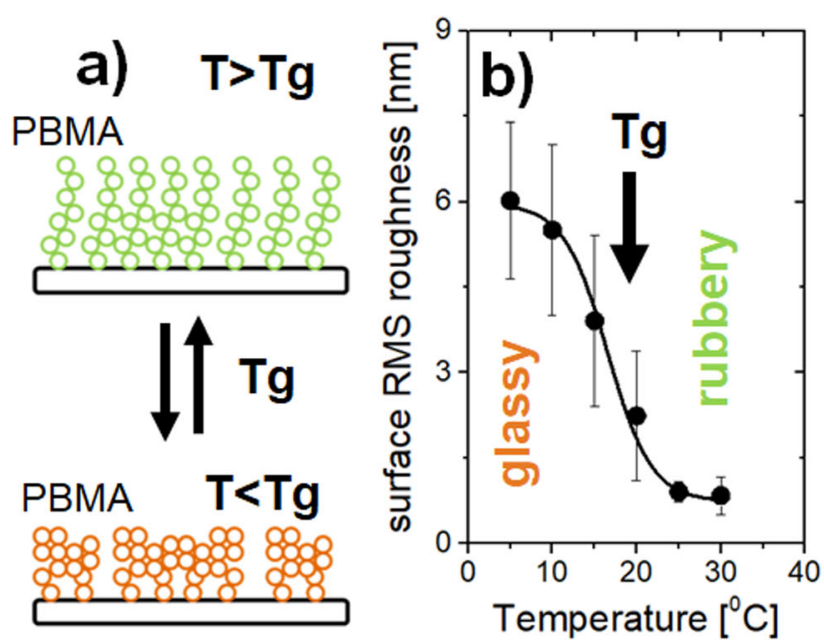

Fig. 8 Properties of the temperature-responsive poly(n-butyl methacrylate) (PBMA)-grafted brush attached to the glass, with a temperature sensitivity based on glassy-to-rubbery state transition [75]. (a) Hypothetical scheme of temperature sensitivity. (b-d) Temperatureinduced changes around glass transition $T_{g}$ (around $13-25^{\circ} \mathrm{C}$ ) in $(\mathbf{b})$ the surface topography of the brush - from a structured to smooth surface, as measured by the RMS roughness (from AFM), (c) elastic modulusexemplified by the bulk polymer values [130, 131], (d) adsorption of

PBMA-grafted brushes at different temperatures, is presented in Fig. 9. The scores plot shows that the first principal component PC1 separates the PBMA brush samples from the reference glass samples. In turn, the second PC2 captures the difference originating from the BSA adsorbed below and above $T_{g}$, with the data points centered for negative and positive PC2 values, respectively (Fig. 9d). Modification of the protein's state can be concluded. To interpret further the data, the PC2 loadings plot (Fig. 9b) is used, analyzed with respect to two hypotheses, i.e., the changes of protein orientation (Fig. 9b) or conformation (Fig. 9c). First, 3 domains (Albumin 1, 2, 3) of BSA are considered, and the negative values of the loadings on the PC2 are related to the mass signals of amino acids more abundant in Albumin 1 and Albumin 2 than Albumin 3. In turn, the PC2 is loaded positively by the fragments of amino acids rich in Albumin 3 when compared with Albumin 1 and Albumin 2. Second, no correlation between the PC2 loadings and conformation changes can be indicated (Fig. 9c), using the analysis applied earlier for the same BSA protein (Fig. 5a). In particular, no systematic dependence can be noticed for the loadings on the PC2 plotted for each amino acid as a function of its side-chain hydrophobicity (Fig. 9c). Therefore, the differences in the composition of the outermost region of the adsorbed protein layer, as revealed by the PCA, suggest changes in the BSA orientation. The concluded temperature-controlled change of BSA orientation (sketched in Fig. 9a), leads to the exposure of Albumin 3 at higher temperatures, enhancing the formation of BSA dimers [132], and increasing the BSA adsorption (Fig. 8d).

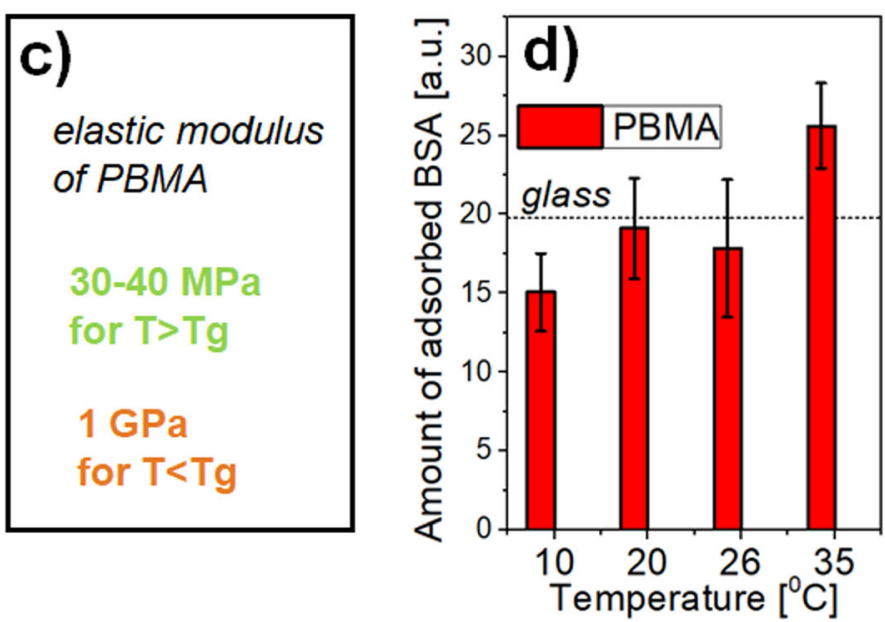

BSA on the brush (compared with that on glass). In turn, variations of the polar (van der Waals-London) and apolar (hydrogen bonding) components of the PBMA surface energy are small $(<9 \%)$. The major factors controlling temperature-dependent proteins' orientation (Figs. 9 and 10) are surface topography (b) and polymer elasticity (c) effects, while the electrostatic interactions of the PBMA brush with differently charged protein domains are disregarded as they yield opposite predictions for BSA and the anti-IgG (cf. Figs. 9a and 10a)

\section{Temperature-controlled proteins' orientation and biological activity}

Temperature-controlled proteins' orientation provided by the temperature-responsive PBMA-grafted brushes is demonstrated also for the anti-IgG antibody adsorbed at various temperatures. A PCA analysis of the mass signals originating from the amino acids of this protein is shown in Fig. 10b, c. The scores plot shows that the first principal component PC1 separates the brush samples with the antibody adsorbed below and above $T_{g}$, with the data points described by positive and negative PC1 values, respectively (Fig. 10c). The first PC is interpreted using the analysis applied earlier to determine antibody orientation (Fig. 6a). Therefore, the loadings on the PC1 from the TOF-SIMS signals of the anti-IgG (Fig. 10b) are plotted as a function of the relative prevalence, RP, of the amino acids contributing to each signal and originating from the $\mathrm{F}(\mathrm{ab})_{2}$ versus the $\mathrm{Fc}$ fragment. The positive and negative PC1 scores (Fig. 10c) are induced by positive and negative loadings on the PC1 (Fig. 10b). Therefore, it can be concluded (Fig. 10b) that the uppermost regions of the antibodies adsorbed to the brush below and above $T_{g}$ are dominated by the $\mathrm{F}\left(\mathrm{ab}{ }^{\prime}\right)_{2}$ domains (negative $\mathrm{RP}$ ) and $\mathrm{Fc}$ domains (positive RP), respectively. Hence, the orientation change of the anti$\mathrm{IgG}$ antibody from an end-on to a head-on alignment, induced by temperature increased above $T_{g}$ of the brush (Fig. 10a). Independently, the assay shows that the effectiveness of IgG binding to the pre-adsorbed anti- $\operatorname{IgG}$ is higher for an anti-IgG adsorbed at a temperature below $T_{g}$ of the brush compared with the situation above $T_{g}$ (Fig. 10d). This indicates that an 

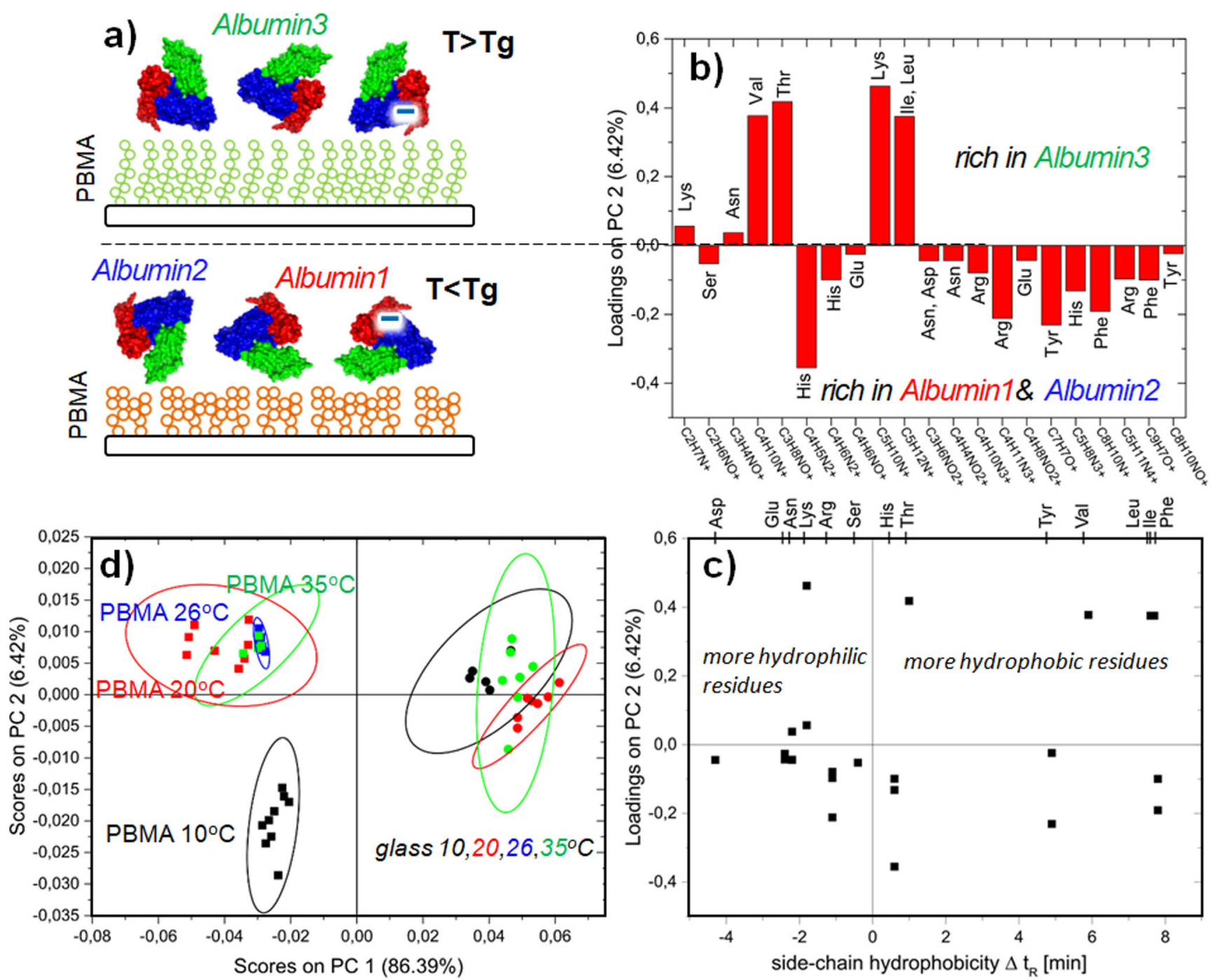

Fig. 9 (a) Temperature controlled orientation of BSA, with resolved 3 domains (Albumin 1,2,3), adsorbed on temperature-responsive PBMAgrafted brushes at different temperatures. (b, c) Multivariate analysis [75]: (b) loadings plot shows that the PC2 is loaded negatively by the mass signals of amino acids (e.g., His, Tyr) more abundant in Albumin 1 and Albumin 2 than Albumin 3. In turn, the PC2 is loaded positively by the signals of amino acids (e.g., Val, Thr) rich in Albumin 3 when compared with Albumin 1 and Albumin 2. (c) No correlation between the PC2 loadings and the conformational can be indicated (based on an analysis

anti-IgG antibody adsorbed onto PBMA brushes preserves its biological activity and confirms its temperature-dependent orientation.

\section{Summary and conclusions}

Information about the state, i.e., the conformation and orientation, of different proteins immobilized on various molecular and polymer surfaces are readily provided by the multivariate TOFSIMS method, which combines an excellent chemical specificity with surface sensitivity. Determining changes in a protein's similar to that of Fig. 5a). (d) The scores on PC2 separate the samples of BSA adsorbed to PBMA-grafted brushes at temperatures below and above the glass transition $T_{g}$. In contrast, the data of the reference samples with PBMA adsorbed on the glass are distributed around a zero PC2 value independently of the temperature itself. The concluded BSA orientation change leads to the exposure of Albumin 3 at higher temperatures, enhancing the formation of BSA dimers [132], and increasing the BSA adsorption (Fig. 8d)

orientation correlate well with protein biorecognition, as demonstrated through binding assays for streptavidin-biotin (Fig. 7) and antibody-antigen pairs (Fig. 10) [33, 37]. Also, the determined conformation changes of immobilized protein are confirmed by AFM morphology images of protein coverage, modified by denaturation (Fig. 5). This underlines the potential of the multivariate TOF-SIMS method for a reliable (although performed in vacuum) characterization of surface-immobilized proteins, providing information about their state in a more direct manner than most other surface analysis methods [22, 24, 37].

Control over the state of surface-immobilized proteins, critical for biointerface engineering, can be achieved by the 
a)
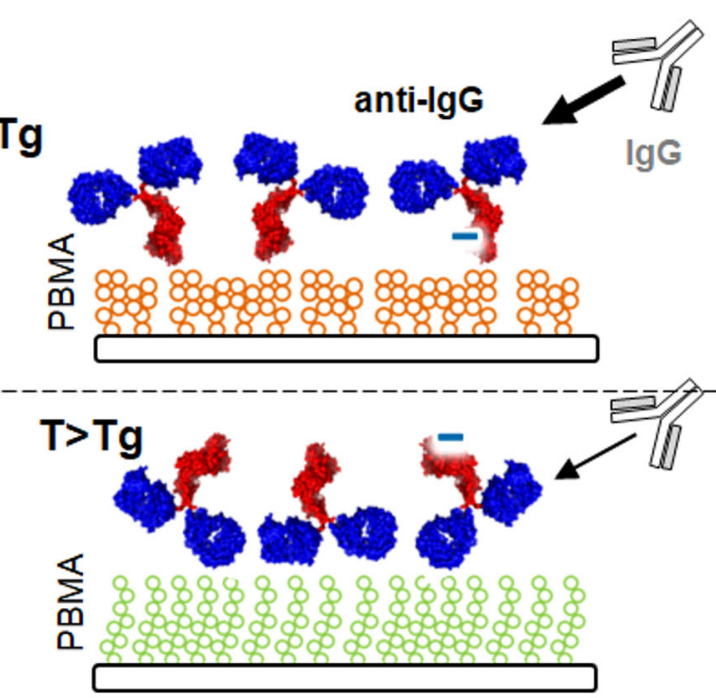

d)

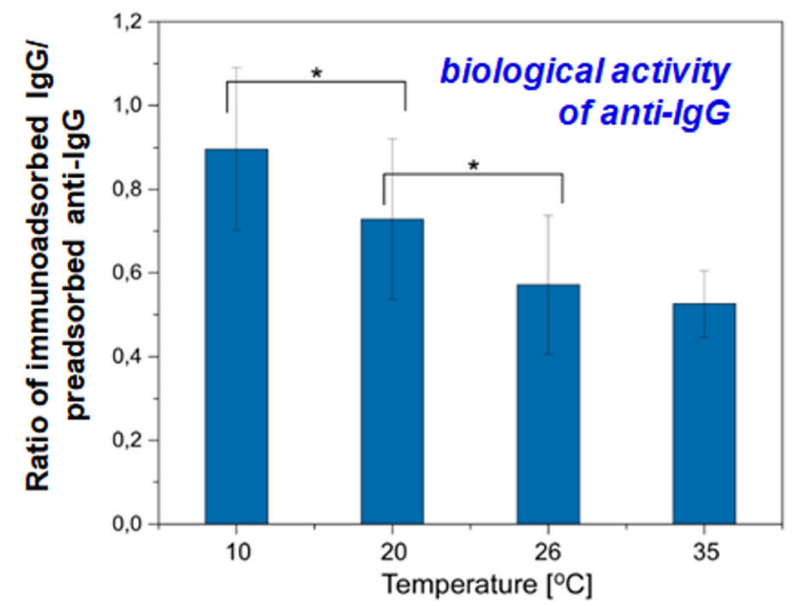

Fig. 10 (a) Temperature controlled orientation [75] of the anti-IgG (secondary) antibody adsorbed on temperature-responsive grafted PBMA brushes at various temperatures, analyzed with PCA (b, c), modifying the biological activity of the protein (d). (b) Loadings on the PC1 from the mass signals of the anti-IgG antibody plotted as a function of the relative prevalence, $\mathrm{RP}$, of amino acids contributing to each signal and originating from the $\mathrm{F}(\mathrm{ab})_{2}$ versus the Fc fragment (cf. Fig. 6a). (c) The

design of surfaces and immobilization conditions, through different types of protein-surface and protein-protein interactions. Protein denaturation can be induced by hydrophobic surface-polymer interactions (Fig. 5). In turn, protein orientation is controlled through the electrostatic interactions of the dipoles of the adsorbed proteins (Figs. 3 and 6) or their subunits (Fig. 7), adjusted by a buffer $\mathrm{pH}$ for selfassembled monolayers (Fig. 3), or by the effective electric field imposed by solution-cast semi-crystalline films, in the case of electroactive conjugated polymers (Figs. 6 and 7). Since the greatest magnitude of the latter effect is observed for PQT12, this conductive polythiophene might be an interesting alternative for RP3HT commonly used in OFETbased biosensors. Orienting the electrostatic interactions of an antibody with the surface can be supplemented by

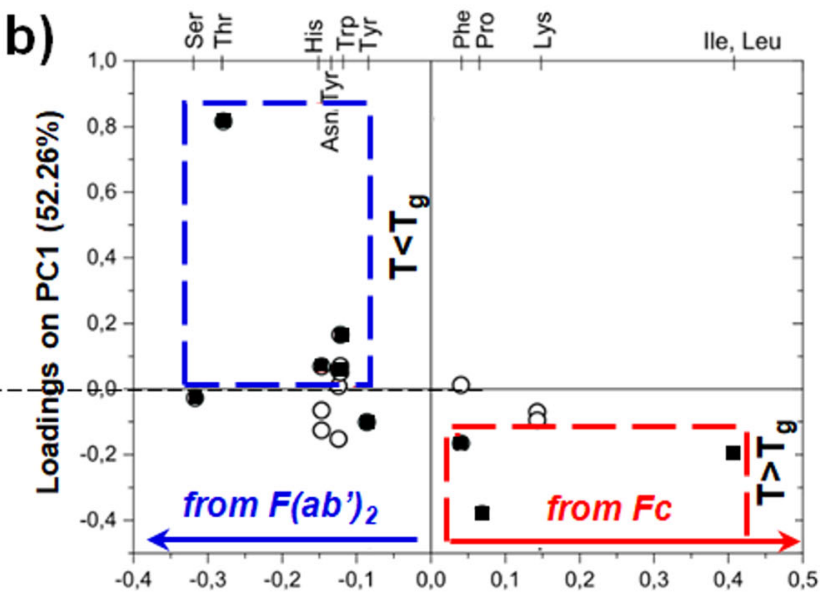

relative prevalence (RP) of amino acids

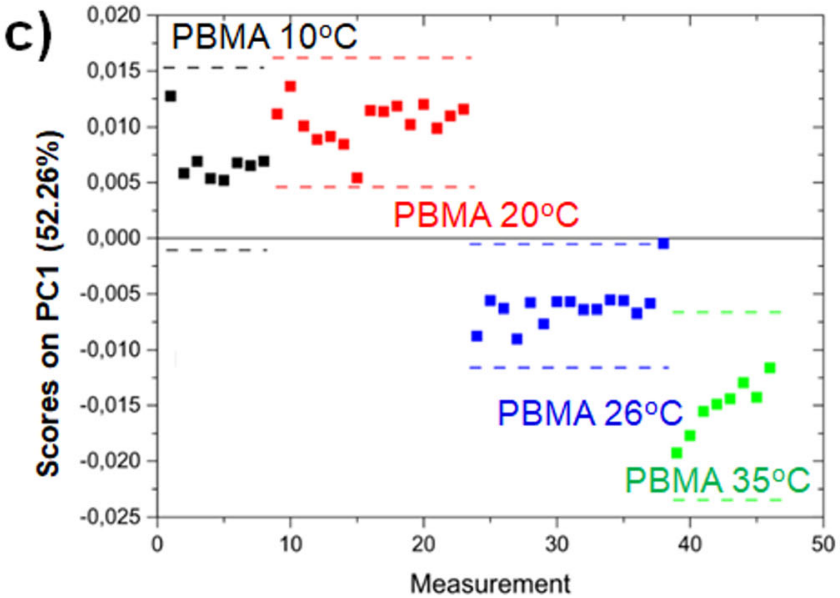

scores on the PC1 separate the samples of the anti-IgG antibody adsorbed to PBMA grafted brushes at temperatures below and above the glass transition $T_{g}$. Hence, dominant antibody orientation changes with temperature from end-on $\left(T<T_{g}\right)$ to head-on $\left(T>T_{g}\right)$. (d) Biological activity of the anti- $\mathrm{IgG}$, determined at various temperatures as the ratio of the surface amounts of $\operatorname{IgG}$ (after binding to pre-adsorbed anti-IgG) and the anti-IgG

specific binding with pre-adsorbed antigens (Fig. 3) or suppressed by electrostatic intermolecular interactions inducing an anti-ferroelectric order of antibody dipoles (Fig. 6). Also, surface density induces orientation changes of antibodies, packed randomly in a monolayer due to their repulsive short-ranged intermolecular interactions (Fig. 2). For covalently immobilized antibodies, the different reactivity of different protein's domains promotes specific orientations (Fig. 2). Finally, nanostructured surface topography and/ or surface elasticity effects (Figs. 9 and 10), lead to a controlled orientation of different proteins on temperatureresponsive polymer brushes. Here, the temperature control of protein orientation and biological activity offers an interesting strategy to obtain remote biorecognition control, or to fabricate switchable biosensing platforms. 
In recent years, several extensions of the well-established and widely applied multivariate TOF-SIMS analysis of the protein state have been developed. The examination of the orientation of immobilized proteins now involves not only antibodies but also different proteins such as BSA (Fig. 9) or streptavidin (Fig. 7). The analysis of antibody orientation is no longer limited to antibodies immobilized on various surfaces but involves also those embedded in the layers with different protein components (Fig. 3), for instance, related to the immunoassay protocols for silicon-based biosensors. Moreover, simultaneous analysis of several samples with different antibodies surface densities, through data projection on a previously developed PCA model, enables the determination of surface density ranges characteristic for different antibody orientations, that accords with the random rather than the commonly assumed close packing of proteins (Fig. 2). The ability of multivariate TOF-SIMS analysis to trace the orientation changes of various proteins ( $\operatorname{IgG}$ and BSA) induced by environmental stimuli, such as temperature (Figs. 9 and 10) is important for the development of functional platforms based on stimuli-responsive polymer brushes. As has recently been shown, the results of a PCA analysis of protein orientation can be correlated with binding assay results, for the antibody-antigen (Fig. 10) and the streptavidin-biotin (Fig. 7) recognition, providing the full picture of the orientation related to biorecognition efficacy. In turn, for the analysis of protein conformation changes the relationship between PCA loadings and the side-chain hydrophobicity of different amino acids (Figs. 5 and 9), instead of the commonly used simplified classification as merely hydrophobic or hydrophilic residues, leads to both a more lucid and appropriate interpretation.

Funding information This work was supported by the Polish National Science Center (NCN) under Grants 2016/21/N/ST5/00880, 2011/03/N/ ST5/04764, and 2016/21/D/ST5/01633. K.G. is grateful for the financial support from the Foundation for Polish Science (FNP) (within the framework of the START scholarship).

\section{Compliance with ethical standards}

Conflict of interest The authors declare that they have no conflict of interest.

Open Access This article is licensed under a Creative Commons Attribution 4.0 International License, which permits use, sharing, adaptation, distribution and reproduction in any medium or format, as long as you give appropriate credit to the original author(s) and the source, provide a link to the Creative Commons licence, and indicate if changes were made. The images or other third party material in this article are included in the article's Creative Commons licence, unless indicated otherwise in a credit line to the material. If material is not included in the article's Creative Commons licence and your intended use is not permitted by statutory regulation or exceeds the permitted use, you will need to obtain permission directly from the copyright holder. To view a copy of this licence, visit http://creativecommons.org/licenses/by/4.0/.

\section{References}

1. Okano T, Yamada N, Sakai H, Sakurai Y (1993) A novel recovery system for cultured cells using plasma-treated polystyrene dishes grafted with poly(N-isopropylacrylamide). J Biomed Mater Res 27:1243-1251. https://doi.org/10.1002/jbm.820271005

2. Senaratne W, Andruzzi L, Ober CK (2005) Self-assembled monolayers and polymer brushes in biotechnology: current applications and future perspectives. Biomacromolecules 6:2427-2448. https://doi.org/10.1021/bm050180a

3. Samanta D, Sarkar A (2011) Immobilization of biomacromolecules on self-assembled monolayers: methods and sensor applications. Chem Soc Rev 40:2567-2592. https://doi. org/10.1039/c0cs00056f

4. Wink T, Van Zuilen SJ, Bult A, Van Bennekom WP (1997) Selfassembled monolayers for biosensors. Analyst 122:43R-50R. https://doi.org/10.1039/a606964i

5. Pagkali V, Petrou PS, Salapatas A, Makarona E, Peters J, Haasnoot W, Jobst G, Economou A, Misiakos K, Raptis I, Kakabakos SE (2017) Detection of ochratoxin A in beer samples with a label-free monolithically integrated optoelectronic biosensor. J Hazard Mater 323:75-83. https://doi.org/10.1016/j.jhazmat. 2016.03.019

6. Angelopoulou M, Botsialas A, Salapatas A, Jobst G, Goustouridis D, Siafaka-kapadai A (2015) Assessment of goat milk adulteration with a label-free monolithically integrated optoelectronic biosensor. Anal Bioanal Chem 407:3995-4004. https://doi.org/10.1007/ s00216-015-8596-3

7. Pagkali V, Petrou PS, Makarona E, Peters J, Haasnoot W, Jobst G, Moser I, Gajos K, Budkowski A, Economou A, Raptis I, Kakabakos SE (2018) Simultaneous determination of aflatoxin $\mathrm{B}_{1}$, fumonisin $\mathrm{B}_{1}$ and deoxynivalenol in beer samples with a label-free monolithically integrated optoelectronic biosensor. J Hazard Mater 359:445-453. https://doi.org/10.1016/j.jhazmat. 2018.07.080

8. Bañuls MJ, Puchades R, Maquieira Á (2013) Chemical surface modifications for the development of silicon-based label-free integrated optical (IO) biosensors: a review. Anal Chim Acta 777:116. https://doi.org/10.1016/j.aca.2013.01.025

9. Holzer B, Manoli K, Ditaranto N, Macchia E, Tiwari A, Di Franco C, Scamarcio G, Palazzo G, Torsi L (2017) Characterization of covalently bound anti-human immunoglobulins on self-assembled monolayer modified gold electrodes. Adv Biosyst 1:1700055. https://doi.org/10.1002/adbi.201700055

10. Meyers SR, Grinstaff MW (2012) Biocompatible and bioactive surface modifications for prolonged in vivo efficacy. Chem Rev 112:1615-1632. https://doi.org/10.1021/cr2000916

11. Gajos K, Guzenko VA, Dübner M, Haberko J, Budkowski A, Padeste C (2016) Electron-beam lithographic grafting of functional polymer structures from fluoropolymer substrates. Langmuir 32:10641-10650. https://doi.org/10.1021/acs.langmuir.6b02808

12. Higaki Y, Kobayashi M, Murakami D, Takahara A (2016) Antifouling behavior of polymer brush immobilized surfaces. Polym J 48:325-331. https://doi.org/10.1038/pj.2015.137

13. Cole MA, Voelcker NH, Thissen H, Griesser HJ (2009) Stimuliresponsive interfaces and systems for the control of proteinsurface and cell-surface interactions. Biomaterials 30:18271850. https://doi.org/10.1016/j.biomaterials.2008.12.026

14. Minko S (2008) Grafting on solid surfaces: "grafting to" and "grafting from" methods. In: Manfred S (ed) Polymer surfaces and interfaces. Springer, pp 2015-2234

15. Edmondson S, Osborne VLV, Huck WTSW (2004) Polymer brushes via surface-initiated polymerizations. Chem Soc Rev 33: 14-22. https://doi.org/10.1039/b210143m 
16. Zhao B, Brittain WJ (2000) Polymer brushes: surfaceimmobilized macromolecules. Prog Polym Sci 25:677-710. https://doi.org/10.1016/S0079-6700(00)00012-5

17. Kumar A, Srivastava A, Galaev IY, Mattiasson B (2007) Smart polymers: physical forms and bioengineering applications. Prog Polym Sci 32:1205-1237. https://doi.org/10.1016/j.progpolymsci. 2007.05.003

18. Jeong B, Gutowska A (2002) Lessons from nature: stimuli-responsive polymers and their biomedical applications. Trends Biotechnol 20: 305-311. https://doi.org/10.1016/S0167-7799(02)01962-5

19. Synytska A, Svetushkina E, Puretskiy N, Stoychev G, Berger S, Ionov L, Bellmann C, Eichhorn K-J, Stamm M (2010) Biocompatible polymeric materials with switchable adhesion properties. Soft Matter 6:5907-5914. https://doi.org/10.1039/ c0sm00414f

20. Rabe M, Verdes D, Seeger S (2011) Understanding protein adsorption phenomena at solid surfaces. Adv Colloid Interf Sci 162: 87-106. https://doi.org/10.1016/j.cis.2010.12.007

21. Gray JJ (2004) The interaction of proteins with solid surfaces. Curr Opin Struct Biol 14:110-115. https://doi.org/10.1016/j.sbi. 2003.12.001

22. Trilling AK, Beekwilder J, Zuilhof H (2013) Antibody orientation on biosensor surfaces: a minireview. Analyst 138:1619-1627. https://doi.org/10.1039/c2an36787d

23. Gopinath SCB, Tang TH, Citartan M, Chen Y, Lakshmipriya T (2014) Current aspects in immunosensors. Biosens Bioelectron 57:292-302. https://doi.org/10.1016/j.bios.2014.02.029

24. Welch NG, Scoble JA, Muir BW, Pigram PJ (2017) Orientation and characterization of immobilized antibodies for improved immunoassays (review). Biointerphases 12:02D301. https://doi.org/ 10.1116/1.4978435

25. Vilhena JG, Dumitru AC, Herruzo ET, Mendieta-Moreno JI, Garcia R, Serena PA, Pérez R (2016) Adsorption orientations and immunological recognition of antibodies on graphene. Nanoscale 8:13463-13475. https://doi.org/10.1039/c5nr07612a

26. Chen S, Liu L, Zhou J, Jiang S (2003) Controlling antibody orientation on charged self-assembled monolayers. Langmuir 19: 2859-2864. https://doi.org/10.1021/la026498v

27. Makky A, Berthelot T, Feraudet-Tarisse C, Volland H, Viel P, Polesel-Maris J (2012) Substructures high resolution imaging of individual IgG and IgM antibodies with piezoelectric tuning fork atomic force microscopy. Sensors Actuators B Chem 162:269 277. https://doi.org/10.1016/j.snb.2011.12.077

28. Kosobrodova E, Jones RT, Kondyurin A, Chrzanowski W, Pigram PJ, Mckenzie DR, Bilek MMM (2015) Orientation and conformation of anti-CD34 antibody immobilised on untreated and plasma treated polycarbonate. Acta Biomater 19:128-137. https://doi.org/10.1016/j.actbio.2015.02.027

29. Castner DG (2017) Biomedical surface analysis: evolution and future directions (review). Biointerphases 12:02C301. https://doi. org/10.1116/1.4982169

30. Michel R, Castner DG (2006) Advances in time-of-flight secondary ion mass spectrometry analysis of protein films. Surf Interface Anal 38:1386-1392. https://doi.org/10.1002/sia.2382

31. Wagner MS, Horbett TA, Castner DG (2003) Characterization of the structure of binary and ternary adsorbed protein films using electron spectroscopy for chemical analysis, time-of-flight secondary ion mass spectrometry, and radiolabeling. Langmuir 19: 1708-1715. https://doi.org/10.1021/la0260382

32. Xia N, May CJ, McArthur SL, Castner DG (2002) Time-of-flight secondary ion mass spectrometry analysis of conformational changes in adsorbed protein films. Langmuir 18:4090-4097. https://doi.org/10.1021/la020022u

33. Liu F, Dubey M, Takahashi H, Castner DG, Grainger DW (2010) Immobilized antibody orientation analysis using secondary ion mass spectrometry and fluorescence imaging of affinity- generated patterns. Anal Chem 82:2947-2958. https://doi.org/10. $1021 /$ ac $902964 \mathrm{q}$

34. Gajos K, Szafraniec K, Petrou P, Budkowski A (2020) Surface density dependent orientation and immunological recognition of antibody on silicon: TOF-SIMS and surface analysis of two covalent immobilization methods. Appl Surf Sci 518:146269. https:// doi.org/10.1016/J.APSUSC.2020.146269

35. Awsiuk K, Budkowski A, Petrou P, Marzec MM, Biernat M, Jaworska-Gołąb T, Rysz J (2016) Orientation and biorecognition of immunoglobulin adsorbed on spin-cast poly(3alkylthiophenes): impact of polymer film crystallinity. Colloids Surf B: Biointerfaces 148:278-286. https://doi.org/10.1016/j. colsurfb.2016.08.028

36. Welch NG, Madiona RMT, Scoble JA, Muir BW, Pigram PJ (2016) ToF-SIMS and principal component analysis investigation of denatured, surface-adsorbed antibodies. Langmuir 32:10824 10834. https://doi.org/10.1021/acs.langmuir.6b02754

37. Lebec V, Boujday S, Poleunis C, Pradier C-M, Delcorte A (2014) Time-of-flight secondary ion mass spectrometry investigation of the orientation of adsorbed antibodies on sams correlated to biorecognition tests. J Phys Chem C 118:2085-2092. https://doi. org $/ 10.1021 / \mathrm{jp} 410845 \mathrm{~g}$

38. Wagner MS, Castner DG (2001) Characterization of adsorbed protein films by time-of-flight secondary ion mass spectrometry with principal component analysis. Langmuir 17:4649-4660. https://doi.org/10.1021/la001209t

39. Henry M, Dupont-Gillain C, Bertrand P (2003) Conformation change of albumin adsorbed on polycarbonate membranes as revealed by ToF-SIMS. Langmuir 19:6271-6276. https://doi.org/ 10.1021/la034081z

40. Kempson IM, Martin AL, Denman JA, French PW, Prestidge CA, Barnes TJ (2010) Detecting the presence of denatured human serum albumin in an adsorbed protein monolayer using TOF-SIMS. Langmuir 26:12075-12080. https://doi.org/10.1021/la101253g

41. Mantust DS, Ratner BD, Carlson BA, Moulder JF (1993) Static secondary ion mass spectrometry of adsorbed proteins. Anal Chem 65:1431-1438. https://doi.org/10.1021/ac00058a021

42. Vickerman JC, Briggs D (2013) TOF-SIMS: materials analysis by mass spectrometry2nd edn. IM Publications LLP

43. Muramoto S, Brison J, Castner DG (2012) Exploring the surface sensitivity of TOF-secondary ion mass spectrometry by measuring the implantation and sampling depths of $\mathrm{Bi}$ n and $\mathrm{C} 60$ ions in organic films. Anal Chem 84:365-372. https://doi.org/10.1021/ac202713k

44. Kim Y-P, Hong M-Y, Kim J, Oh E, Shon HK, Moon DW, Kim H-S, Lee TG (2007) Quantitative analysis of surface-immobilized protein by TOF-SIMS: effects of protein orientation and trehalose additive. Anal Chem 79:1377-1385. https://doi.org/10.1021/ac0616005

45. Xia N, Castner DG (2003) Preserving the structure of adsorbed protein films for time-of-flight secondary ion mass spectrometry analysis. J Biomed Mater Res - Part A 67:179-190. https://doi. org/10.1002/jbm.a.10063

46. Yu J, Zhou Y, Hua X, Zhu Z, Yu X-Y (2016) In situ characterization of hydrated proteins in water by SALVI and ToF-SIMS. J Vis Exp 2016:e53708. https://doi.org/10.3791/53708

47. Yu J, Zhou Y, Engelhard M, Zhang Y, Son J, Liu S, Zhu Z, Yu X$Y$ (2020) In situ molecular imaging of adsorbed protein films in water indicating hydrophobicity and hydrophilicity. Sci Rep 10: 3695. https://doi.org/10.1038/s41598-020-60428-1

48. Zhou Y, Yao J, Ding Y, Yu J, Hua X, Evans JE, Yu X, Lao DB, Heldebrant DJ, Nune SK, Wang X-L, Zhu Z (2016) Improving the molecular ion signal intensity for in situ liquid SIMS analysis. J Am Soc Mass Spectrom 27:2006-2013. https://doi.org/10.1007/ s13361-016-1478-x

49. Son JG, Yoon S, Shon HK, Moon JH, Joh S, Lee TG (2020) Argas cluster ion beam in ToF-SIMS for peptide and protein analysis. Biointerphases 15:021011. https://doi.org/10.1116/6.0000105 
50. Van Nuffel S, Parmenter C, Scurr DJ, Russell NA, Zelzer M (2016) Multivariate analysis of 3D ToF-SIMS images: method validation and application to cultured neuronal networks. Analyst 141:90-95. https://doi.org/10.1039/c5an01743b

51. Oshima S, Kashihara I, Moritani K, Inui N, Mochiji K (2011) Soft-sputtering of insulin films in argon-cluster secondary ion mass spectrometry. Rapid Commun Mass Spectrom 25:10701074. https://doi.org/10.1002/rcm.4959

52. Makarov A (2000) Electrostatic axially harmonic orbital trapping: a high-performance technique of mass analysis. Anal Chem 72: 1156-1162. https://doi.org/10.1021/ac991131p

53. Passarelli MK, Pirkl A, Moellers R, Grinfeld D, Kollmer F, Havelund R, Newman CF, Marshall PS, Arlinghaus H, Alexander MR, Dollery CT, Gilmore IS (2017) The 3D OrbiSIMS - label-free metabolic imaging with subcellular lateral resolution and high mass-resolving power. Nat Methods 14:11751183. https://doi.org/10.1038/nmeth.4504

54. Graham DJ, Castner DG (2012) Multivariate analysis of ToFSIMS data from multicomponent systems: the why, when, and how. Biointerphases 7:1-12. https://doi.org/10.1007/s13758012-0049-3

55. Welch NG, Madiona RMT, Payten TB, Easton CD, Pontes-Braz L, Brack N, Scoble JA, Muir BW, Pigram PJ (2017) Surface immobilized antibody orientation determined using ToF-SIMS and multivariate analysis. Acta Biomater 55:172-182. https:// doi.org/10.1016/j.actbio.2017.03.038

56. Tyler BJ, Rayal G, Castner DG (2007) Multivariate analysis strategies for processing ToF-SIMS images of biomaterials. Biomaterials 28:2412-2423. https://doi.org/10.1016/j. biomaterials.2007.02.002

57. Park J-W, Min H, Kim Y-P, Shon HK, Kim J, Moon DW, Lee TG (2009) Multivariate analysis of ToF-SIMS data for biological applications. Surf Interface Anal 41:694-703. https://doi.org/10. 1002/sia.3049

58. Lee C-Y, Harbers GM, Grainger DW, Gamble LJ, Castner DG (2007) Fluorescence, XPS, and TOF-SIMS surface chemical state image analysis of DNA microarrays. J Am Chem Soc 129:94299438. https://doi.org/10.1021/ja071879m

59. Cumpson PJ, Sano N, Fletcher IW, Portoles JF, Bravo-Sanchez M, Barlow AJ (2015) Multivariate analysis of extremely large ToFSIMS imaging datasets by a rapid PCA method. Surf Interface Anal 47:986-993. https://doi.org/10.1002/sia.5800

60. Tuccitto N, Giamblanco N, Marletta G, Licciardello A (2008) ToF-SIMS investigation of FIB-patterning of lactoferrin by using self-assembled monolayers of iron complexes. Appl Surf Sci 255: 1075-1078. https://doi.org/10.1016/j.apsusc.2008.05.106

61. Pawlicki AA, Borodinov N, Giri N, Moore S, Brown C, Belianinov A, Ievlev AV, Ovchinnikova OS (2019) Multimodal chemical imaging for linking adhesion with local chemistry in agrochemical multicomponent polymeric coatings. Anal Chem 91:2791-2796. https://doi.org/10.1021/acs.analchem.8b04607

62. Trindade GF, Abel M-L, Lowe C, Tshulu R, Watts JF (2018) A time-of-flight secondary ion mass spectrometry/multivariate analysis (ToF-SIMS/MVA) approach to identify phase segregation in blends of incompatible but extremely similar resins. Anal Chem 90:3936-3941. https://doi.org/10.1021/acs.analchem.7b04877

63. Konicek AR, Lefman J, Szakal C (2012) Automated correlation and classification of secondary ion mass spectrometry images using a k-means cluster method. Analyst 137:3479-3487. https://doi.org/10.1039/c2an16122b

64. Kassenböhmer R, Heeger M, Dwivedi M, Körsgen M, Tyler BJ, Galla H-J, Arlinghaus HF (2018) 3D molecular ToF-SIMS imaging of artificial lipid membranes using a discriminant analysisbased algorithm. Langmuir 34:8750-8757. https://doi.org/10. 1021/acs.langmuir.8b01253
65. Najafinobar N, Venkatesan S, von Sydow L, Klarqvist M, Olsson H, Zhou X-H, Cloonan SM, Malmberg P (2019) ToF-SIMS mediated analysis of human lung tissue reveals increased iron deposition in COPD (GOLD IV) patients. Sci Rep 9:10060. https://doi. org/10.1038/s41598-019-46471-7

66. Sanni OD, Wagner MS, Briggs D, Castner DG, Vickerman JC (2002) Classification of adsorbed protein static ToF-SIMS spectra by principal component analysis and neural networks. Surf Interface Anal 33:715-728. https://doi.org/10.1002/sia.1438

67. Welch NG, Madiona RMT, Payten TB, Jones RT, Brack N, Muir BW, Pigram PJ (2016) Surface adsorbed antibody characterization using ToF-SIMS with principal component analysis and artificial neural networks. Langmuir 32:8717-8728. https://doi.org/10. 1021/acs.langmuir.6b02312

68. Gardner W, Cutts SM, Muir BW, Jones RT, Pigram PJ (2019) Visualizing ToF-SIMS Hyperspectral imaging data using colortagged Toroidal self-organizing maps. Anal Chem 91:1385513865. https://doi.org/10.1021/acs.analchem.9b03322

69. Madiona RMT, Winkler DA, Muir BW, Pigram PJ (2019) Effect of mass segment size on polymer ToF-SIMS multivariate analysis using a universal data matrix. Appl Surf Sci 478:465-477. https:// doi.org/10.1016/j.apsusc.2019.01.242

70. Madiona RMT, Bamford SE, Winkler DA, Muir BW, Pigram PJ (2018) Distinguishing chemically similar polyamide materials with ToF-SIMS using self-organizing maps and a universal data matrix. Anal Chem 90:12475-12484. https://doi.org/10.1021/acs. analchem. $8 \mathrm{~b} 01951$

71. Madiona RMT, Welch NG, Muir BW, Winkler DA, Pigram PJ (2019) Rapid evaluation of immobilized immunoglobulins using automated mass-segmented ToF-SIMS. Biointerphases 14: 061002. https://doi.org/10.1063/1.5121450

72. Harrison ET, Wang Y-C, Carter L, Castner DG (2020) Characterizing protein $\mathrm{G} B 1$ orientation and its effect on immunoglobulin $\mathrm{G}$ antibody binding using XPS, ToF-SIMS, and quartz crystal microbalance with dissipation monitoring. Biointerphases 15:021002. https://doi.org/10.1116/1.5142560

73. Wang H, Castner DG, Ratner BD, Jiang S (2004) Probing the orientation of surface-immobilized immunoglobulin $\mathrm{G}$ by timeof-flight secondary ion mass spectrometry. Langmuir 20:18771887. https://doi.org/10.1021/la035376f

74. Gajos K, Budkowski A, Pagkali V, Petrou P, Biernat M, Awsiuk K, Rysz J, Bernasik A, Misiakos K, Raptis I, Kakabakos S (2016) Indirect immunoassay on functionalized silicon surface: molecular arrangement, composition and orientation examined step-by-step with multi-technique and multivariate analysis. Colloids Surf B: Biointerfaces 150:437-444. https://doi.org/10.1016/j.colsurfb. 2016.11.009

75. Awsiuk K, Stetsyshyn Y, Raczkowska J, Lishchynskyi O, Dabczyński P, Kostruba A, Ohar H, Shymborska Y, Nastyshyn S, Budkowski A (2019) Temperature-controlled orientation of proteins on temperature-responsive grafted polymer brushes: poly(butyl methacrylate) vs poly(butyl acrylate): morphology, wetting, and protein adsorption. Biomacromolecules 20:21852197. https://doi.org/10.1021/acs.biomac.9b00030

76. Park J-W, Cho I-H, Moon DW, Paek S-H, Lee TG (2011) ToFSIMS and PCA of surface-immobilized antibodies with different orientations. Surf Interface Anal 43:285-289. https://doi.org/10. 1002/sia.3440

77. Awsiuk K, Petrou P, Thanassoulas A, Raczkowska J (2019) Orientation of biotin-binding sites in streptavidin adsorbed onto the surface of Polythiophene films. Langmuir 35:3058-3066. https://doi.org/10.1021/acs.langmuir.8b03509

78. Baio JE, Weidner T, Baugh L, Gamble LJ, Stayton PS, Castner DG (2012) Probing the orientation of electrostatically immobilized protein G B1 by time-of-flight secondary ion spectrometry, sum frequency generation, and near-edge X-ray 
adsorption fine structure spectroscopy. Langmuir 28:2107-2112. https://doi.org/10.1021/la203907t

79. Giamblanco N, Zhavnerko G, Tuccitto N, Licciardello A, Marletta G (2012) Coadsorption-dependent orientation of fibronectin epitopes at hydrophilic gold surfaces. Soft Matter 8:8370-8378. https://doi.org/10.1039/c2sm25490e

80. Okada K, Aoyagi S, Dohi M, Kato N, Kudo M, Tozu M, Miyayama T, Sanada N (2008) Evaluation of immobilizedlysozyme by means of TOF-SIMS. Appl Surf Sci 255:11041106. https://doi.org/10.1016/j.apsusc.2008.05.050

81. Scudeller LA, Srinivasan S, Rossi AM, Stayton PS, Drobny GP, Castner DG (2017) Orientation and conformation of osteocalcin adsorbed onto calcium phosphate and silica surfaces. Biointerphases 12:02D411. https://doi.org/10.1116/1.4983407

82. Aoyagi S, Rouleau A, Boireau W (2008) TOF-SIMS structural characterization of self-assembly monolayer of cytochrome b5 onto gold substrate. Appl Surf Sci 255:1071-1074. https://doi. org/10.1016/j.apsusc.2008.05.086

83. Lebec V, Landoulsi J, Boujday S, Poleunis C, Pradier C-M, Delcorte A (2013) Probing the orientation of $\beta$-lactoglobulin on gold surfaces modified by alkyl thiol self-assembled monolayers. J Phys Chem C 117:11569-11577. https://doi.org/10.1021/ jp311964g

84. Awsiuk K, Budkowski A, Marzec MM, Petrou P, Rysz J, Bernasik A (2014) Effects of polythiophene surface structure on adsorption and conformation of bovine serum albumin: a multivariate and multitechnique study. Langmuir 30:13925-13933. https://doi.org/10.1021/la502646w

85. Michel R, Pasche S, Textor M, Castner DG (2005) Influence of PEG architecture on protein adsorption and conformation. Langmuir 21:12327-12332. https://doi.org/10.1021/la051726h

86. Foster RN, Harrison ET, Castner DG (2016) ToF-SIMS and XPS characterization of protein films adsorbed onto bare and sodium styrenesulfonate-grafted gold substrates. Langmuir 32:32073216. https://doi.org/10.1021/acs.langmuir.5b04743

87. Killian MS, Krebs HM, Schmuki P (2011) Protein denaturation detected by time-of-flight secondary ion mass spectrometry. Langmuir 27:7510-7515. https://doi.org/10.1021/la200704s

88. Tidwell CD, Castner DG, Golledge SL, Ratner BD, Meyer K, Hagenhoff B, Benninghoven A (2001) Static time-of-flight secondary ion mass spectrometry and $\mathrm{x}$-ray photoelectron spectroscopy characterization of adsorbed albumin and fibronectin films. Surf Interface Anal 31:724-733. https://doi.org/10.1002/sia.1101

89. Joyce P, Kempson I, Prestidge CA (2016) Orientating lipase molecules through surface chemical control for enhanced activity: a QCM-D and ToF-SIMS investigation. Colloids Surf B: Biointerfaces 142:173-181. https://doi.org/10.1016/j.colsurfb. 2016.02.059

90. Makaraviciute A, Ramanaviciene A (2013) Site-directed antibody immobilization techniques for immunosensors. Biosens Bioelectron 50:460-471. https://doi.org/10.1016/J.BIOS.2013. 06.060

91. Caroselli R, Castelló JG, Escorihuela J, Bañuls MJ, Maquieira Á, García-Rupérez J (2018) Experimental study of the oriented immobilization of antibodies on photonic sensing structures by using protein a as an intermediate layer. Sensors (Switzerland) 18:1012. https://doi.org/10.3390/s18041012

92. Trilling AK, Harmsen MM, Ruigrok VJB, Zuilhof H, Beekwilder J (2013) The effect of uniform capture molecule orientation on biosensor sensitivity: dependence on analyte properties. Biosens Bioelectron 40:219-226. https://doi.org/10.1016/j.bios.2012.07. 027

93. Stavra E, Petrou PS, Koukouvinos G, Economou A, Goustouridis D, Misiakos K, Raptis I, Kakabakos SE (2020) Fast, sensitive and selective determination of herbicide glyphosate in water samples with a white light reflectance spectroscopy immunosensor.
Talanta 214:120854. https://doi.org/10.1016/j.talanta.2020. 120854

94. Anastasiadis V, Koukouvinos G, Petrou PS, Economou A, Dekker J, Harjanne M, Heimala P, Goustouridis D, Raptis I, Kakabakos SE (2020) Multiplexed mycotoxins determination employing white light reflectance spectroscopy and silicon chips with silicon oxide areas of different thickness. Biosens Bioelectron 153:112035. https://doi.org/10.1016/j.bios.2020. 112035

95. Koukouvinos G, Goustouridis D, Misiakos K, Kakabakos S, Raptis I, Petrou P (2018) Rapid C-reactive protein determination in whole blood with a white light reflectance spectroscopy labelfree immunosensor for point-of-care applications. Sensors Actuators B Chem 260:282-288. https://doi.org/10.1016/j.snb. 2018.01.008

96. Misiakos K, Makarona E, Hoekman M, Fyrogenis R, Tukkiniemi K, Jobst G, Petrou PS, Kakabakos SE, Salapatas A, Goustouridis D, Harjanne M, Heimala P, Raptis I (2019) All-silicon spectrally resolved Interferometric circuit for multiplexed diagnostics: a monolithic lab-on-a-chip integrating all active and passive components. ACS Photonics 6:1694-1705. https://doi.org/10.1021/ acsphotonics.9b00235

97. González-Guerrero AB, Maldonado J, Herranz S, Lechuga LM (2016) Trends in photonic lab-on-chip interferometric biosensors for point-of-care diagnostics. Anal Methods 8:8380-8394. https:// doi.org/10.1039/c6ay02972h

98. Gajos K, Budkowski A, Tsialla Z, Petrou P, Awsiuk K, Dąbczyński P, Bernasik A, Rysz J, Misiakos K, Raptis I, Kakabakos S (2017) Contact pin-printing of albumin-fungicide conjugate for silicon nitride-based sensors biofunctionalization: multi-technique surface analysis for optimum immunoassay performance. Appl Surf Sci 410:79-84. https://doi.org/10.1016/j. apsusc.2017.03.100

99. Awsiuk K, Bernasik A, Kitsara M, Budkowski A, Petrou P, Kakabakos S, Prauzner-Bechcicki S, Rysz J, Raptis I (2012) Spectroscopic and microscopic characterization of biosensor surfaces with protein/amino-organosilane/silicon structure. Colloids Surf B: Biointerfaces 90:159-168. https://doi.org/10.1016/j. colsurfb.2011.10.017

100. Gajos K, Angelopoulou M, Petrou P, Awsiuk K, Kakabakos S, Haasnoot W, Bernasik A, Rysz J, Marzec MM, Misiakos K, Raptis I, Budkowski A (2016) Imaging and chemical surface analysis of biomolecular functionalization of monolithically integrated on silicon Mach-Zehnder interferometric immunosensors. Appl Surf Sci 385:529-542. https://doi.org/10.1016/j.apsusc.2016.05. 131

101. Wiseman ME, Frank CW (2012) Antibody adsorption and orientation on hydrophobic surfaces. Langmuir 28:1765-1774. https:// doi.org/10.1021/la203095p

102. Buijs J, Lichtenbelt JWT, Norde W, Lyklema J (1995) Adsorption of monoclonal IgGs and their $\mathrm{F}\left(\mathrm{ab}^{\prime}\right)_{2}$ fragments onto polymeric surfaces. Colloids Surf B: Biointerfaces 5:11-23. https://doi.org/ 10.1016/0927-7765(95)98205-2

103. Adamczyk Z (2012) Modeling adsorption of colloids and proteins Curr Opin Colloid Interface Sci 17:173-186. https://doi.org/10. 1016/j.cocis.2011.12.002

104. Chen S, Liu L, Zhou J, Jiang S (2003) Controlling antibody orientation on charged self-assembled monolayers. Langmuir 19: 2859-2864. https://doi.org/10.1021/la026498v

105. Chen H, Huang J, Lee J, Hwang S, Koh K (2010) Surface plasmon resonance spectroscopic characterization of antibody orientation and activity on the calixarene monolayer. Sensors Actuators B Chem 147:548-553. https://doi.org/10.1016/j.snb.2010.03.033

106. Mouri M, Ikawa T, Narita M, Hoshino F, Watanabe O (2010) Orientation control of photo-immobilized antibodies on the surface of azobenzene-containing polymers by the introduction of 
functional groups. Macromol Biosci 10:612-620. https://doi.org/ 10.1002/mabi.200900394

107. Wallace G, Spinks G (2007) Conducting polymers - bridging the bionic interface. Soft Matter 3:665. https://doi.org/10.1039/ b618204f

108. Wallace GG, Kane-Maguire LAP (2002) Manipulating and monitoring biomolecular interactions with conducting electroactive polymers. Adv Mater 14:953-960. https://doi.org/10.1002/15214095(20020704)14:13/14<953::AID-ADMA953>3.0.CO;2-W

109. Monera OD, Sereda TJ, Zhou NE, Kay CM, Hodges RS (1995) Relationship of sidechain hydrophobicity and $\alpha$-helical propensity on the stability of the single-stranded amphipathic $\alpha$-helix. J Pept Sci 1:319-329. https://doi.org/10.1002/psc.310010507

110. Albers WM, Pelto JM, Suspène C, Määttä JA, Yassar A, Hytönen VP, Vikholm-Lundin IM, Tappura K (2012) Structural and functional characteristics of chimeric avidins physically adsorbed onto functionalized polythiophene thin films. ACS Appl Mater Interfaces 4:4067-4077. https://doi.org/10.1021/am3008517

111. Lin P, Yan F (2012) Organic thin-film transistors for chemical and biological sensing. Adv Mater 24:34-51. https://doi.org/10.1002/ adma.201103334

112. Manoli K, Magliulo M, Mulla MY, Singh M, Sabbatini L, Palazzo G, Torsi L (2015) Printable bioelectronics to investigate functional biological interfaces. Angew Chem Int Ed 54:12562-12576. https://doi.org/10.1002/anie.201502615

113. Higgins MJ, Molino PJ, Yue Z, Wallace GG (2012) Organic conducting polymer-protein interactions. Chem Mater 24:828839. https://doi.org/10.1021/cm203138j

114. Scarpa G, Idzko A-L, Götz S, Thalhammer S (2010) Biocompatibility studies of functionalized regioregular poly(3hexylthiophene) layers for sensing applications. Macromol Biosci 10:378-383. https://doi.org/10.1002/mabi.200900412

115. Widge AS, Jeffries-El M, Cui X, Lagenaur CF, Matsuoka Y (2007) Self-assembled monolayers of polythiophene conductive polymers improve biocompatibility and electrical impedance of neural electrodes. Biosens Bioelectron 22:1723-1732. https:// doi.org/10.1016/j.bios.2006.08.011

116. Tiwari S, Singh AK, Joshi L, Chakrabarti P, Takashima W, Kaneto K, Prakash R (2012) Poly-3-hexylthiophene based organic field-effect transistor: detection of low concentration of ammonia. Sensors Actuators B Chem 171-172:962-968. https://doi.org/10. 1016/j.snb.2012.06.010

117. Fukuda H, Ise M, Kogure T, Takano N (2004) Gas sensors based on poly-3-hexylthiophene thin-film transistors. Thin Solid Films 464-465:441-444. https://doi.org/10.1016/j.tsf.2004.06.004

118. Pernites RB, Santos CM, Maldonado M, Ponnapati RR, Rodrigues DF, Advincula RC (2012) Tunable protein and bacterial cell adsorption on colloidally templated superhydrophobic polythiophene films. Chem Mater 24:870-880. https://doi.org/ $10.1021 / \mathrm{cm} 2007044$

119. Salleo A (2007) Charge transport in polymeric transistors. Mater Today 10:38-45. https://doi.org/10.1016/S1369-7021(07)700184

120. Chen TA, Wu X, Rieke RD (1995) Regiocontrolled synthesis of poly(3-alkylthiophenes) mediated by Rieke zinc: their characterization and solid-state properties. J Am Chem Soc 117:233-244

121. Kang S-J, Song S, Liu C, Kim D-Y, Noh Y-Y (2014) Evolution in crystal structure and electrical performance of thiophene-based polymer field effect transistors: a remarkable difference between thermal and solvent vapor annealing. Org Electron 15:1972-1982. https://doi.org/10.1016/j.orgel.2014.05.026

122. Mouhib T, Delcorte A, Poleunis C, Henry M, Bertrand P (2010) $\mathrm{C}_{60}$ SIMS depth profiling of bovine serum albumin proteincoating films: a conformational study. Surf Interface Anal 42: 641-644. https://doi.org/10.1002/sia.3349
123. Budkowski A, Klein J, Fetters LJ (1995) Brush formation by symmetric and by highly asymmetric diblock copolymers at homopolymer interfaces. Macromolecules 28:8571-8578. https:// doi.org/10.1021/ma00129a016

124. Budkowski A, Klein J, Steiner U, Fetters LJ (1993) Diblock copolymers attached to homopolymer surfaces and interfaces. Macromolecules 26:2470-2478. https://doi.org/10.1021/ ma00062a012

125. Barbey R, Lavanant L, Paripovic D, Schüwer N, Sugnaux C, Tugulu S, Klok H-A (2009) Polymer brushes via surfaceinitiated controlled radical polymerization: synthesis, characterization, properties, and applications. Chem Rev 109:5437-5527. https://doi.org/10.1021/cr900045a

126. Yamada N, Okano T, Sakai H, Karikusa F, Sawasaki Y, Sakurai Y (1990) Thermo-responsive polymeric surfaces; control of attachment and detachment of cultured cells. Macromol Rapid Commun 11:571-576

127. Stetsyshyn Y, Zemla J, Zolobko O, Fornal K, Budkowski A, Kostruba A, Donchak V, Harhay K, Awsiuk K, Rysz J, Bernasik A, Voronov S (2012) Temperature and $\mathrm{pH}$ dualresponsive coatings of oligoperoxide-graft-poly $(\mathrm{N}-$ isopropylacrylamide): wettability, morphology, and protein adsorption. J Colloid Interface Sci 387:95-105. https://doi.org/10. 1016/j.jcis.2012.08.007

128. Stetsyshyn Y, Fornal K, Raczkowska J, Zemla J, Kostruba A, Ohar H, Ohar M, Donchak V, Harhay K, Awsiuk K, Bernasik A, Budkowski A (2013) Temperature and $\mathrm{pH}$ dual-responsive POEGMA-based coatings for protein adsorption. J Colloid Interface Sci 411:247-256. https://doi.org/10.1016/j.jcis.2013. 08.007

129. Cheng X, Canavan HE, Graham DJ, Castner DG, Ratner BD (2006) Temperature dependent activity and structure of adsorbed proteins on plasma polymerized $\mathrm{N}$-isopropyl acrylamide. Biointerphases 1:61-72. https://doi.org/10.1116/1.2187980

130. Chyasnavichyus M, Young SL, Tsukruk VV (2014) Probing of polymer surfaces in the viscoelastic regime. Langmuir 30:1056610582. https://doi.org/10.1021/la404925h

131. Cappella B, Kaliappan SK, Sturm H (2005) Using AFM forcedistance curves to study the glass-to-rubber transition of amorphous polymers and their elastic-plastic properties as a function of temperature. Macromolecules 38:1874-1881. https://doi.org/ 10.1021/ma040135f

132. Rezwan K, Meier LP, Rezwan M, Vo J, Textor M, Gauckler LJ (2004) Bovine serum albumin adsorption onto colloidal Al 2 O 3 particles: a new model based on zeta potential and UV - Vis measurements. Langmuir 23:10055-10061

133. Lord MS, Foss M, Besenbacher F (2010) Influence of nanoscale surface topography on protein adsorption and cellular response. Nano Today 5:66-78. https://doi.org/10.1016/j.nantod.2010.01. 001

134. Roach P, Eglin D, Rohde K, Perry CC (2007) Modern biomaterials: a review - bulk properties and implications of surface modifications. J Mater Sci Mater Med 18:1263-1277. https://doi.org/ 10.1007/s10856-006-0064-3

135. Berglin M, Pinori E, Sellborn A, Andersson M, Hulander M, Elwing H (2009) Fibrinogen adsorption and conformational change on model polymers: novel aspects of mutual molecular rearrangement. Langmuir 25:5602-5608. https://doi.org/10. 1021/la803686m

Publisher's note Springer Nature remains neutral with regard to jurisdictional claims in published maps and institutional affiliations. 


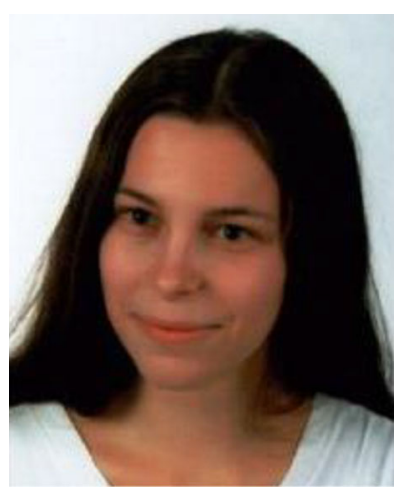

Katarzyna Gajos graduated from Jagiellonian University in Kraków in 2017 with a Ph.D. in Biophysics under supervision of Prof. Andrzej Budkowski. After the graduation she works as an assistant professor at her alma mater. Her research interests cover biomolecular nanolayers, micropatterns and biosensor surfaces, their characterization with surface science methods, including TOFSIMS spectrometry.

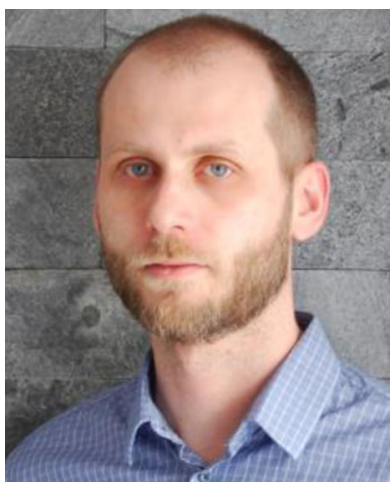

Kamil Awsiuk graduated from Jagiellonian University in Kraków in 2013 with a Ph.D. in Biophysics under supervision of Prof. Andrzej Budkowski. After the graduation he works as an assistant $(2013-2016)$ and assistant professor (since 2016) at Jagiellonian University, where hecompleted his habilitation in 2020. His research mainly focuses on organic materials for plastic electronics and biomedical applications, characterization of molecular and polymer surfaces and their interactions with proteins, cells and bacteria.

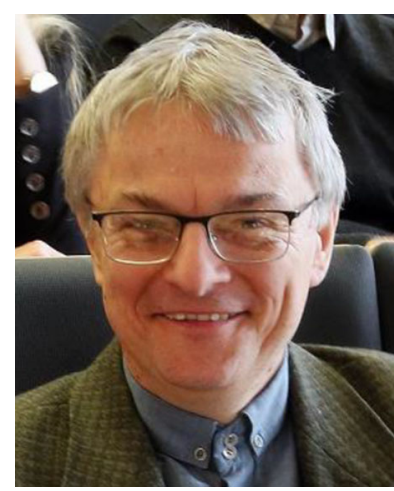

Andrzej Budkowski graduated from Jagiellonian University, Kraków, in 1989 with a Ph.D. in Physics under the supervision of Prof. Velibor Marinković and Dr. Albert Prodan, for a research started at the Jožef Stefan Institute, Ljubljana. Then, he joined the Weizmann Institute of Science, Rehovot (1989-95), as a postdoc and a visiting scientist in Prof. Jacob Klein's group. After moving back to Jagiellonian University, he completed his habilitation (1998), earned a title and a position of a professor (2004) and became a professor ordinarius (2011). His research focused on interfacial phenomena and polymer blends. Since 2011, his main interests are bio-macromolecules at surfaces, biosensor surfaces and controllable biointerfaces. 